\title{
Arms and ammunitions: effectors at the interface of rice and it's pathogens and pests
}

Sohini Deb ${ }^{1,2}$, Vishnu Narayanan Madhavan' ${ }^{1}$ C. G. Gokulan ${ }^{1}$, Hitendra K. Patel ${ }^{1 *}$ and Ramesh V. Sonti ${ }^{1,3^{*}}$ (D)

\begin{abstract}
The plant immune system has evolved to resist attack by pathogens and pests. However, successful phytopathogens deliver effector proteins into plant cells where they hijack the host cellular machinery to suppress the plant immune responses and promote infection. This manipulation of the host cellular pathways is done by the pathogen using various enzymatic activities, protein- DNA or protein- protein interactions. Rice is one the major economically important crops and its yield is affected by several pathogens and pests. In this review, we summarize the various effectors at the plant- pathogen/ pest interface for the major pathogens and pests of rice, specifically, on the mode of action and target genes of the effector proteins. We then compare this across the major rice pathogens and pests in a bid to understand probable conserved pathways which are under attack from pathogens and pests in rice. This analysis highlights conserved patterns of effector action, as well as unique host pathways targeted by the pathogens and pests.
\end{abstract}

Keywords: Rice, Effectors, Immunity, Pathogen, Pest, Disease

\section{Background}

The growing global population necessitates increased food production even as resources such as water and land are becoming limiting and environmental concerns dictate lesser use of inputs such as fertilizers and pesticides. To ensure food security and sustainable agricultural practices, the development of newer crop varieties is necessary. This involves addressing various aspects, such as yield and tolerance to biotic and abiotic stresses. The biotic stresses include plant diseases caused by bacteria, fungi and viruses as well as damage caused by nematodes and insect pests. Understanding the molecular intricacies of these plant-pathogen/pest interactions can be an important aid in developing disease tolerant plant varieties. A major role in the success of these pathogens and pests is played by the class of molecules, known as

\footnotetext{
*Correspondence: hkpatel@ccmb.res.in; sonti@ccmb.res.in

${ }^{1}$ CSIR-Centre for Cellular and Molecular Biology (CSIR-CCMB),

Hyderabad 500007, India

Full list of author information is available at the end of the article
}

"effectors". Effectors secreted by pathogens/pests can function in gaining entry into the plant, obtaining access to its nutrients, to suppress host defense responses and to eventually multiply in or on the plant. These effectors can either be proteins or metabolites. Because of their importance in promoting infection/infestation, a better understanding of effector biology can potentially help in conceptualizing newer strategies for developing biotic stress tolerant plant varieties. Numerous reviews have extensively covered effector biology from the perspective of the pathogens (Franceschetti et al. 2017; Dean et al. 2012; Toruno et al. 2016; Varden et al. 2017; Dou and Zhou 2012). This article aims to review effectors deployed by the pathogens and pests of rice and identify any common strategies that they may be targeting.

Oryza sativa, or rice, is the staple food for nearly half of the global population and is an economically important crop across nations (Khush 2005). Its production is constantly threatened by many different diseases/ pests. On an average, farmers lose an estimated $37 \%$ of their rice crop to diseases and pests every year (http:// 
www.knowledgebank.irri.org). Various pathogens and pests have been described in rice, although the biology of their effectors has been explored only in a few of the major pathogens. Two members of the bacterial genus Xanthomonas cause the serious bacterial blight (BB) and bacterial leaf streak (BLS) diseases. Magnaporthe ory$z a e$ causes blast of rice and is a well-established fungal disease model in rice. Other emerging rice- pathogen disease models among filamentous pathogens include the fungus Rhizoctonia solani and Pythium oomycetes species. About 20 species of insects are known to cause significant economic damage in rice (http://www.knowl edgebank.irri.org). Some important pests of the rice plant include brown plant hopper (BPH), gall midge and yellow stem borer.

Research on rice-pathogen/pest interaction at the molecular level is a very active field and warrants more investigation. This review seeks to highlight the information available for rice in a comprehensive manner, also emphasizing on the need for further characterisation of the host targets of effectors secreted by pathogens and pests.

\section{Main Text}

\section{Bacterial Pathogens: Microscopic but Devastating}

Xanthomonas includes a large group of plant pathogenic Gram- negative bacteria which infect more than 200 different plant species (Boch and Bonas 2010; Buttner and Bonas 2010). Depending on the host range, and symptomology on a host, they have been grouped into different pathovars (pv.) (Dye et al. 1980). The primary mode of entry for Xanthomonas bacteria into rice plants are natural openings like stomata and hydathodes. $X$. oryzae pv. oryzae (Xoo) causes bacterial blight (BB) and X. oryzae pv. oryzicola (Xoc) causes bacterial leaf streak (BLS) in rice. Infection sites are characterised by water-soaked lesions and chlorosis, and often become necrotic. Xoo and Xoc use effectors secreted through different types of protein secretion systems, such as the type II secretion system (T2SS) and the type III secretion system (T3SS) (Fig. 1). Effectors can thus be divided into two broad groups: those acting in the extracellular spaces of host tissues (apoplastic) or those acting within host cells (cytoplasmic) (Carella et al. 2018). Apoplastic effectors are secreted via the T2SS of bacterial pathogens (Chang et al. 2014). These molecules are typically involved in the enzymatic degradation of plant cell walls, immune evasion, or the suppression of host proteolytic activity (Toruno et al. 2016; Wang and Wang 2018). The cell wall degrading enzymes secreted by Xoo serve to breach the cell wall, but the damage that they cause also triggers host immune responses (Fig. 1). To suppress and evade host immune responses, Xoo secretes effector proteins into plant cells via its T3SS. The T3SS apparatus is a needle-like structure spanning both the bacterial membranes which injects the effectors directly into the plant cell (Weber et al. 2005). Hence these effectors are termed as "cytoplasmic effectors", their site of action being inside the plant cell (Khan et al. 2018). Xanthomonas type III effector proteins are classified either as Transcription activator-like (TAL) effectors which have a DNA binding domain or non-TAL effectors (also known as $\underline{X} a$ thomonas outer proteins or Xops) which lack the same (Buttner and Bonas 2010; White and Yang 2009).

\section{Apoplastic Effectors: The Two-Edged Swords}

As part of its virulence strategy, Xoo secretes a battery of plant cell wall- degrading enzymes (CWDEs) using its T2SS (Jha et al. 2005, 2007). The Xoo genome contains a single gene cluster encoding for proteins of the type II secretion system (Lee et al. 2005). The T2SS secreted CWDEs are important virulence determinants of the pathogen (Ray et al. 2000; Tayi et al. 2016a, 2016b; Rajeshwari et al. 2005). Action of these CWDEs on the rice cell wall results in damage that is sensed by the host and leads to induction of immune responses.

Proteins secreted by the T2SS include CWDEs such as xylanase (Ray et al. 2000; Rajeshwari et al. 2005; Qian et al. 2013), cellulase/endoglucanase (Sun et al. 2005; Furutani et al. 2004), putative cysteine protease (Furutani et al. 2004), cellobiosidase (Tayi et al. 2016a, 2018), lipase/esterase (Aparna et al. 2009), an extracellular protease EcpA (Zou et al. 2012), endoglucanase EglXoB ( $\mathrm{Hu}$ et al. 2007), etc. A number of these CWDEs have been shown to be required for full virulence on rice and some of them have also been shown to be involved in eliciting host immune responses in planta (Tayi et al. 2016a; Jha et al. 2005). These immune responses are further suppressed by the type III secreted effectors, or the cytoplasmic effectors.

\section{Cytoplasmic Effectors: The Tale of the TALEs}

The cytoplasmic effectors consist of TAL effector proteins (TALEs) and non-TAL effector proteins. The TAL effector proteins enter the nucleus and execute their role as transcription factors by activating the expression of plant susceptibility genes (Boch and Bonas 2010). TAL effector family proteins typically consist of an $\mathrm{N}$-terminal secretion signal and a variable number of near- identical repeats of a 34-amino acid sequence (Mudgett 2005; Bonas et al. 1989; Hopkins et al. 1992). They also have at least one nuclear localisation signal (NLS), and an acidic activation domain (AAD) at the C- terminus (Gurlebeck et al. 2006). Both Xoo and Xoc express a large number of TAL effectors, exceeding eight in Xoo isolates and over twenty in Xoc isolates (Wilkins et al. 2015; Salzberg et al. 


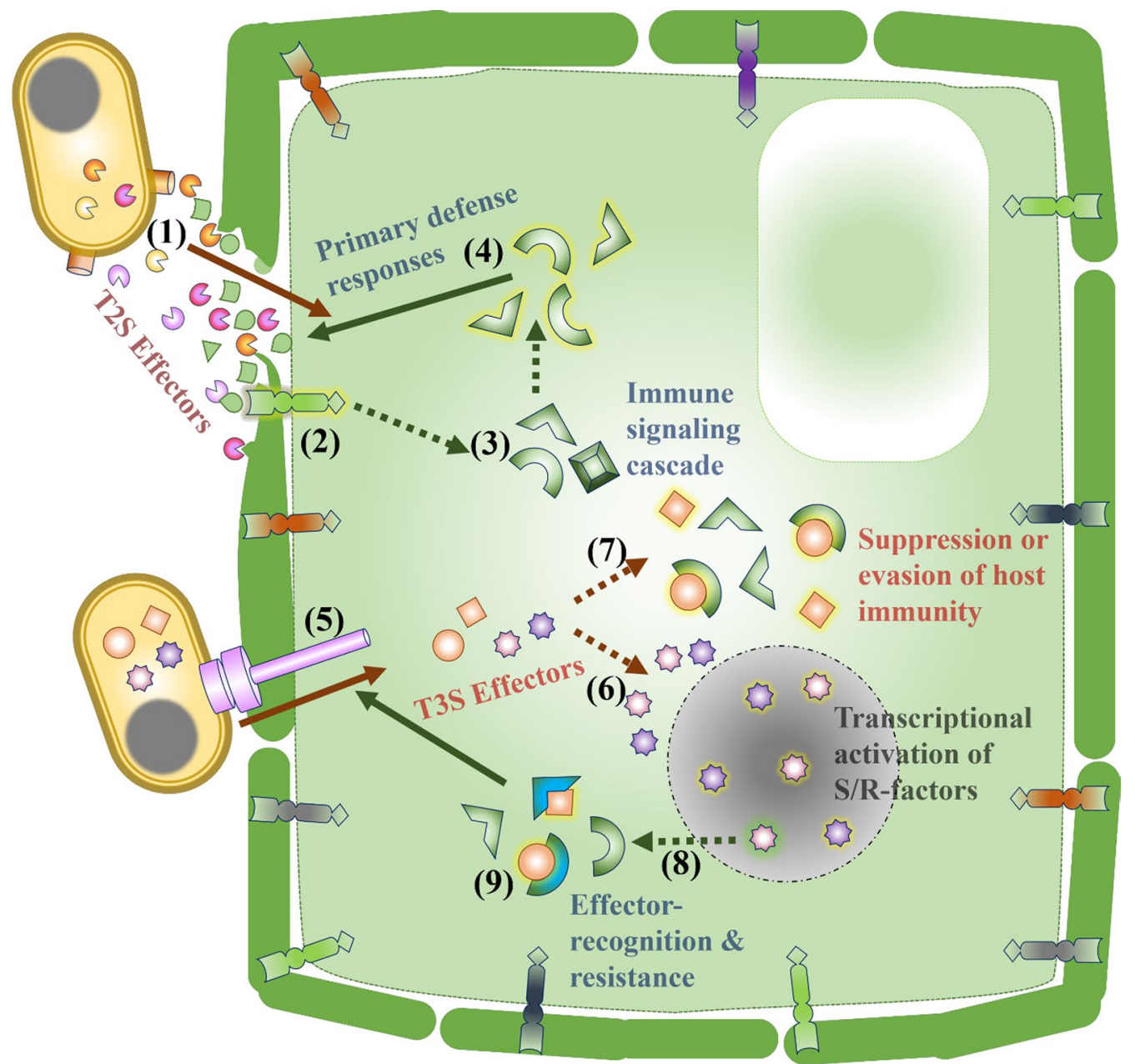

Fig. 1 Overview of rice-Xoo interaction with a focus on effectors during pathogenesis. The Xoo-rice interaction is an example of a complex multi-layered arms race between the pathogen and host with effectors playing remarkable roles in determining the pathogenicity. Xoo gains access to the plant cellular contents through digesting the cell wall. This is achieved via secreting an array of cell wall degrading enzymes (CWDEs, shown as different coloured pie shapes) through the type II secretion system (1). The damage-associated molecular patterns (DAMPs) from degradation products of CWDEs and pathogen-associated molecular patterns (PAMPs) are sensed by specific receptors at the plasma membrane (2). This activates downstream signalling cascades (3) such as MAPK signalling leading to activation of transcription factors and upregulation of defense genes, resulting in defense responses such as callose deposition, programmed cell death, and release of ROS (4). The effector proteins secreted via the type III secretion system are directly delivered into the plant cell cytoplasm (5). These effectors consist of transcription activator-like (TAL) effectors, which are DNA binding proteins that upregulate plant genes leading to further susceptibility (6) (Classical example is SWEET gene upregulation in Xoo-rice interaction). Another class of T3S effectors-non-TAL effectors -are involved in dampening the immune responses by targeting defense signalling pathways, working directly or indirectly by binding to plant proteins (7). The plant counters these effectors using multiple mechanisms. This involves the executor $\mathrm{R}$ genes whose transcription is activated by TAL effectors leading to strong immune response and thus resistance (8), and by resistance proteins that target effectors directly or indirectly (9)

2008; Bogdanove et al. 2011). Some of the most conserved TAL effectors genes are avrXa7, pthXo1, pthXo2 and pthXo3 (Yang and White 2004). Loss of these four effectors from Xoo results in highly reduced virulence and affects symptom development (Bai et al. 2000; Yang and White 2004). The target genes of these effectors are commonly referred to as susceptibility genes. Mutations in the promoters of these genes render these host genes non-responsive to TAL effectors and they function as recessive resistance genes. An alternate response of the plant is a strong suppression of disease development in response to diverse TAL effectors, such as what is mediated by the $X_{o 1}$ resistance locus (Triplett et al. 2016). The target genes of the TAL effectors are a diverse class of genes, the major targets being transcription factors, receptor kinases or SWEET genes (Mücke et al. 2019). 
The well- characterised $R$-genes that confer tolerance against Xoo are Xa1, xa5, Xa7, Xa10, xa13, Xa21, Xa23, $\mathrm{Xa27}$, and $\mathrm{Xa3} / \mathrm{Xa26}$ (Song et al. 1995; Yoshimura et al. 1998; Iyer and McCouch 2004; Sun et al. 2004; Chu et al. 2006b; Gu et al. 2005; Xiang et al. 2006; Wang et al. 2015; Tian et al. 2014; Chen et al. 2021) (Table 1). The Xa21 gene encodes a leucine rich repeat (LRR)-type receptor kinase and interacts with the E3 ligase XB3 (Xa21 Binding Protein 3) (Wang et al. 2006; Song et al. 1995). The elicitor of Xa21 mediated resistance is a sulphatedtyrosine containing peptide secreted by Xoo called RaxX (da Silva et al. 2004; Shen and Ronald 2002; Burdman et al. 2004; Pruitt et al. 2015). xa13 encodes a plasma membrane protein (Chu et al. 2006b), Xa1 encodes a nucleotide-binding site-LRR protein (Yoshimura et al. 1998) and $\mathrm{Xa3} / \mathrm{Xa26}$ encodes an LRR receptor kinaselike protein (Sun et al. 2004; Xiang et al. 2006). Another class of R-genes, called executor R-genes, have also been cloned and characterised. This class include the genes $\mathrm{Xa}$ 7, Xa10, Xa23, and Xa27. Common features of these genes are (i) their expression is observed only in the presence of a cognate TAL effector in the infecting Xoo strain, (ii) the gene induction occurs only in resistant cultivars, (iii) induction of these genes results in hypersensitive response (HR) and thus resistance to Xoo. Xa7, $\mathrm{Xa10}, \mathrm{Xa23}$, and $\mathrm{Xa27}$ were shown to be respectively induced by their cognate TAL effectors and leading to $\mathrm{HR}$ and resistance to Xoo (Gu et al. 2005; Wang et al. 2015; Tian et al. 2014; Chen et al. 2021). Further, Xa10 has been shown to be localised in endoplasmic reticulum (ER) as a hexamer and could trigger cell death by ER $\mathrm{Ca}^{2+}$ depletion via a conserved mechanism (Tian et al. 2014).

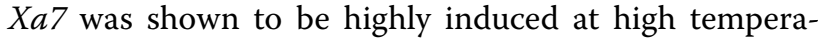
ture regime $\left(35^{\circ} \mathrm{C}\right)$ and is proposed as a suitable source for resistance to Xoo considering the global temperature changes. Notably, among all the TAL effectors that induce executor R-genes, only AvrXa7 has been shown to be essential for Xoo virulence (Chen et al. 2021).

Many of the TALEs target a class of sugar transporters known as the SWEET genes, eg., PthXo1, PthXo6 and PthXo7. The TAL effector PthXo1 binds to the promoter region of OsSWEET11 (also called Os8N3 or $\mathrm{Xa13}$ ), which is a sucrose transporter gene to induce its expression and promote bacterial pathogenicity. The rice gene $x a 13$ is a recessive resistance allele of $O s 8 \mathrm{~N} 3$ (Yang et al. 2006; Antony et al. 2010; Chu et al. 2006a) and is not induced by PthXo1, whereas the susceptible gene $\mathrm{Xa13}$ is pathogen inducible. This recessive allele, however, can be overcome by strains of Xoo producing any one of the type III TAL effectors AvrXa7, PthXo2, or PthXo3. Both AvrXa7 and PthXo3 induce the expression of Os11N3/ OsSWEET14, another SWEET gene which apparently compensates for the inability of Xoo to induce xa13 (Antony et al. 2010; Yuan and Wang 2013). The TAL effector PthXo2 also induces OsSWEET13 (also known as $x a 25$ in the rice cultivar Minghui 63) (Zhou et al. 2015). Thus, TALEs target multiple sugar transporters in the SWEET gene family, likely facilitating sugar export for bacterial consumption (Chen et al. 2010). This has been directly demonstrated for PthXo2 wherein heterologous expression of its target OsSWEET13 in Nicotiana benthamiana leaf cells elevated sucrose concentrations in the leaf apoplasm (Zhou et al. 2015).

Table 1 TAL effectors of $X_{O O}$

\begin{tabular}{|c|c|c|c|}
\hline TAL effector & Target gene & Target gene family & References \\
\hline TalB & OsTFX1 OsERF\#123 & $\begin{array}{l}\text { bZIP transcription factor } \\
\text { AP2/ERF transcription factor }\end{array}$ & Tran et al. (2018) \\
\hline TalC & OSSWEET14 & Plasma membrane protein (sucrose transporter) & Streubel et al. (2013) \\
\hline AvrXa7 & $\begin{array}{l}\text { OSSWEET14/OS11N3 } \\
\text { Xa7 }\end{array}$ & $\begin{array}{l}\text { Plasma membrane protein (sucrose transporter) } \\
\text { Executor R-gene (of unknown function) }\end{array}$ & $\begin{array}{l}\text { Antony et al. (2010), Yuan and } \\
\text { Wang (2013) and Chen et al. } \\
\text { (2021) }\end{array}$ \\
\hline AvrXa10 & Xa10 & $\begin{array}{l}\text { Trans-membrane protein localised to the endoplasmic } \\
\text { reticulum membrane (Executor R-gene) }\end{array}$ & Tian et al. (2014) \\
\hline AvrXa23 & $X a 23$ & Trans-membrane protein (Executor R-gene) & Wang et al. (2014) \\
\hline AvrXa27 & $X a 27$ & Executor R-gene (of unknown function) & Gu et al. (2005) \\
\hline PthXo1 & OsSWEET11/OSBN3 & Plasma membrane protein (sucrose transporter) & Yang et al. (2006) \\
\hline PthXo2 & OsSWEET13/xa25 & Plasma membrane protein (sucrose transporter) & Zhou et al. (2015) \\
\hline PthXo3 Jxov & $\begin{array}{l}\text { CDS1, CDS2, CDS3 } \\
\text { OsSWEET14 }\end{array}$ & $\begin{array}{l}\text { Unknown } \\
\text { Plasma membrane protein (sucrose transporter) }\end{array}$ & Li et al. (2018a) \\
\hline PthXo3 PXO99A & OsSWEET14/Os11N3 & Plasma membrane protein (sucrose transporter) & Antony et al. (2010) \\
\hline PthXo6 & OsTFX1 & bZIP transcription factor & Sugio et al. (2007) \\
\hline PthXo7 & OsTFIIAy 1 & Small subunit of the transcription factor IIA & Sugio et al. (2007) \\
\hline
\end{tabular}


Other targets of Xoo TAL effectors include OsTFX1 and OsTFIIAy 1 , the small subunit of the transcription factor IIA (Sugio et al. 2007). The resistant allele of OsTFIIAy 5 is encoded by $x a 5$ (Iyer and McCouch 2004; Blair et al. 2003). In order to overcome the resistance mediated by $x a 5$, PthXo7 is used by the bacteria to increase the expression of OsTFIIAy 1 (Ma et al. 2018).

More recently, "truncTALEs," for "truncated TAL effectors", alternatively known as interfering TALEs, or iTALEs, have been described in the Xoo strain PXO99A as well as in Xoc BLS256, which suppress disease resistance. As compared to typical TALEs, these proteins lack a transcription activation domain and are expressed from genes that were previously considered pseudogenes (Read et al. 2016; Ji et al. 2016, 2020a).

\section{The Xoo Non-TAL Effectors}

In Xoo, 16 non-TAL effectors were initially identified. Out of these, nine effectors shared homology with previously identified T3S effectors in other plant-pathogenic bacteria whereas seven effectors appeared to be Xoo specific (Furutani et al. 2009). Expression of the type III effectors is regulated by genes that regulate the hrp cluster (hypersensitive response and pathogenicity), specifically, $h r p G$ and $h r p X$ (Song and Yang 2010). Many of these effectors, were shown to be required for the full virulence of the strain (Gupta et al. 2015; Song and Yang 2010; Zhao et al. 2013; Mondal et al. 2016).

True to their putative function, the type III effectors were shown to suppress immune responses. XopZ $Z_{\text {PXO99A }}$ suppressed callose deposition induced by treatment of a T3SS $^{-}$strain (Song and Yang 2010). XopR ${ }_{\text {Xoo }}$ enhances the growth of Xanthomonas campestris pv. campestris T3SS $^{-}$in Arabidopsis, probably by suppression of PAMP (pathogen-associated molecular pattern) -triggered early-defense genes, for example, a leucine-rich repeat protein kinase, a cysteine/histidine-rich $\mathrm{C} 1$ domain family protein, Flg22-induced receptor-like kinase 1 (FRK1) and a member of CYP81F, induced by the T3SS ${ }^{-}$ mutant (Akimoto-Tomiyama et al. 2012). Furthermore, $\mathrm{XopR}_{\text {PXO99A }}$ suppresses PAMP-triggered stomatal closure in transgenic Arabidopsis expressing XopR $\mathrm{PXO99A}_{\text {(Wang }}$ et al. 2016b). Expression of $\mathrm{XopP}_{\mathrm{Xoo}}$ in rice strongly suppresses peptidoglycan (PGN)- and chitin-triggered immunity and tolerance to $X$. oryzae (Ishikawa et al. 2014). XopQ $Q_{\mathrm{BXO43}}$, as well as $\mathrm{XopX}_{\mathrm{BXO43}}$ were shown to suppress plant defense responses by targeting 14-3-3 proteins of rice, which are adapter proteins in signalling pathways (Deb et al. 2019, 2020).

Interestingly, these effectors seem to be targeting a varied number of pathways, indicating towards the involvement of these pathways in immune responses (Table 2). $\mathrm{XopN}_{\mathrm{KXO85}}$ was shown to interact with a thiamine synthase (OsXNP) and OsVOZ2 (a transcription factor) (Cheong et al. 2013). Since treatment with thiamine was shown to enhance resistance to pathogen invasion in rice (Ahn et al. 2005, 2007), XopN seems to suppress immune responses by blocking thiamine synthesis. Another type III non-TAL effector, XopY was shown to inhibit the phosphorylation of the receptor kinase OsRLCK185 and the downstream MAPK signalling, and hence promote pathogenesis (Yamaguchi et al. 2013b). Later it was further shown that this receptor kinase is involved in the perception of both peptidoglycan (PGN) as well as chitin signalling, indicating for its possible involvement in response to bacterial and fungal pathogens (Wang et al. 2017). Another effector which may have a role in interfering with peptidoglycan and chitin induced signalling is the Xoo effector $\mathrm{Xop}_{\mathrm{Xoo}}$, which targets OsPUB44, a rice ubiquitin E3 ligase. $\mathrm{XopP}_{\mathrm{Xoo}}$ was shown to directly interact with the U-box domain of OsPUB44 and inhibit ligase activity. Silencing of OsPUB44 suppressed PGNand chitin-triggered immunity (Ishikawa et al. 2014). On the other hand, XopL itself exhibits E3 ubiquitin ligase activity and interacts with ferredoxin (NbFd), to target it for ubiquitination and ubiquitin-mediated degradation, thereby increasing reactive oxygen species (ROS) production (Ma et al. 2020). XopI has also been shown to act as a F-box adapter and interacts with a thioredoxin protein, OsTrxh2, to strongly inhibit the host's OsNPR1dependent resistance to Xoo (Ji et al. 2020b).

XopAA strongly inhibited host resistance to $X$. oryzae, possibly by interaction with OsBAK1 (BRI1-associated kinase). OsBAK1 interacts with FLS2, the receptor kinase sensor of the PAMP flg22, in the initial steps of its signalling, making it an essential component of signalling responses induced by PAMPs (Chinchilla et al. 2007). OsBAK1 is also a co- receptor of the hormone brassinosteroid (BR) (Wang et al. 2008), suggesting that the virulence promoting activity of XopAA is mediated by the inhibition of OsBAK1 (Yamaguchi et al. 2013a). Similarly, XopR $R_{\text {PXO99A }}$ was shown to interact with BIK1, a receptor-like cytoplasmic kinase (RLCK) and appears to be phosphorylated by it. BIK1 mediates PAMP-triggered stomatal immunity. In addition, XopR was seen to associate with other RLCKs as well apart from BIK1 and thus may suppress plant immunity by targeting RLCKs (Wang et al. 2016b; Akimoto-Tomiyama et al. 2012).

\section{Effectors Employed by Filamentous Pathogens of Rice}

The filamentous pathogens such as fungi and oomycetes are known to cause devastating plant diseases leading to significant yield losses worldwide. Some of the fungal diseases of rice include rice blast caused by Magnaporthe oryzae (M. oryzae), rice sheath blight caused by Rhizoctonia solani, false smut of rice caused by Ustilaginoidea 
Table 2 Non-TAL effectors of Xoo

\begin{tabular}{|c|c|c|}
\hline Effector & Localisation & Pathway inhibited/relevant information \\
\hline XopC & Cytoplasmic (Wang et al. 2016b) & \\
\hline XopF & Chloroplast (predicted) (Zhao et al. 2013) & \\
\hline XopG & & Suppression of XopQ- XopX mediated immune responses (Deb et al. 2020) \\
\hline Xopl & & $\begin{array}{l}\text { Acts as a F-box adapter and interacts with a thioredoxin protein, OsTrxh2, to strongly inhibit the } \\
\text { host's OsNPR1-dependent resistance to Xoo } \\
\text { Required for complete virulence in rice (Ji et al. 2020b) }\end{array}$ \\
\hline XopL & Cytoplasmic (Wang et al. 2016b) & $\begin{array}{l}\text { Exhibits E3 ubiquitin ligase activity and interacts with ferredoxin (NbFd), to target it for ubiquit- } \\
\text { ination and ubiquitin-mediated degradation, thereby increasing reactive oxygen species (ROS) } \\
\text { production (Ma et al. 2020) }\end{array}$ \\
\hline XopN & & $\begin{array}{l}\text { Thiamine synthesis (Cheong et al. 2013) } \\
\text { Suppresses PGN- triggered MAPK activation (Long et al. 2018) }\end{array}$ \\
\hline XopP & Chloroplast (predicted) (Zhao et al. 2013) & $\begin{array}{l}\text { Suppresses PGN- and chitin-triggered immunity and resistance and targets OsPUB44, a rice } \\
\text { ubiquitin E3 ligase (Ishikawa et al. 2014) } \\
\text { Suppression of XopQ- XopX mediated immune responses (Deb et al. 2020) }\end{array}$ \\
\hline XopQ & Nucleo- cytoplasmic (Deb et al. 2019) & $\begin{array}{l}\text { 14-3-3 mediated suppression of rice immune responses (Deb et al. 2019) } \\
\text { Required for complete virulence in rice (Gupta et al. 2015) }\end{array}$ \\
\hline XopR & Plasma membrane (Zhao et al. 2013) & $\begin{array}{l}\text { Receptor kinase interaction (Wang et al. 2016b) } \\
\text { Immune response suppression (Akimoto-Tomiyama et al. 2012) } \\
\text { Required for complete virulence in rice (Zhao et al. 2013) }\end{array}$ \\
\hline XopU & & Suppression of XopQ- XopX mediated immune responses (Deb et al. 2020) \\
\hline XopV & Cytoplasmic (Wang et al. 2016b) & $\begin{array}{l}\text { Suppresses PGN-triggered MAPK activation (Long et al. 2018) } \\
\text { Suppression of XopQ- XopX mediated immune responses (Deb et al. 2020) }\end{array}$ \\
\hline XopW & Cytoplasmic (Wang et al. 2016b) & \\
\hline XopX & Nucleo- cytoplasmic (Deb et al. 2020) & 14-3-3 mediated suppression of rice immune responses (Deb et al. 2020) \\
\hline XopY & & Chitin \& PG induced MAPK signalling (Yamaguchi et al. 2013b) \\
\hline XopZ & & Suppresses PGN- triggered MAPK activation (Long et al. 2018) \\
\hline XopAA & & Receptor kinase interaction \& Brassinosteroid signalling (Yamaguchi et al. 2013a) \\
\hline XopAE & Chloroplast (predicted) (Zhao et al. 2013) & \\
\hline AvrBs2 & & Suppression of XopQ- XopX mediated immune responses (Deb et al. 2020) \\
\hline
\end{tabular}

virens, sheath rot of rice caused by Sarocladium oryzae and bakanae disease caused by Gibberella fujikuroi (Elazegui and Islam 2003). In addition, the oomycete genus Pythium is also known to cause diseases in rice (Van Buyten and Hofte 2013).

The filamentous pathogens have evolved a large repertoire of secreted effectors of various functions, which play a major role in disease progression. With respect to rice-filamentous pathogen biology, the most well-studied pathogen is M. oryzae (Dean et al. 2012; Pennisi 2010). Thus, the scope of this review would primarily be referring to the effectors of $M$. oryzae.

\section{The 'Blast' by Magnaporthe oryzae}

The ascomycete fungus $M$. oryzae, causative agent of rice blast, is classified as one of the most devastating plant pathogens (Pennisi 2010; Dean et al. 2012). During the infection cycle, the fungal spore attaches to the leaf surface, germinates and the germ tube forms a specialised cell called appressorium, which develops the fungal hyphae and uses turgor pressure to insert the hyphae into the plant cell. The fungal hyphae invade plant tissues and cause necrotrophy, leading to disease lesions. M. oryzae gains access into the plant cytoplasm by inserting the invasive hyphae (IH) through the cell wall. The infection strategy of $M$. oryzae is outlined in Fig. 2.

The growing tips of primary $\mathrm{IH}$ and first bulbous $\mathrm{IH}$ retain the biotrophic invasion complex (BIC) which is the specialised region at primary IH for secretion of effectors (Khang et al. 2010; Yan and Talbot 2016). The BIC is a plant membrane-derived structure formed upon the invasion by fungus (Giraldo et al. 2013). Effector secretion at the BIC continues as the IH grow and branch in the plant cell. Through plasmodesmata the IH entering the neighbouring cell forms the BIC again. The BIC structure is a feature of successful infection and is not observed in resistant plants (Mosquera et al. 2009; Khang et al. 2010; Jones et al. 2016; Shipman et al. 2017).

Recently the fungal MAP Kinase, Pathogenicity MAPKinase 1 (PMK1) was shown to control the constriction of $\mathrm{IH}$ at the plasmodesmata to invade the neighbouring cells and regulate the expression of various effectors to suppress rice immune responses (Sakulkoo et al. 2018; 


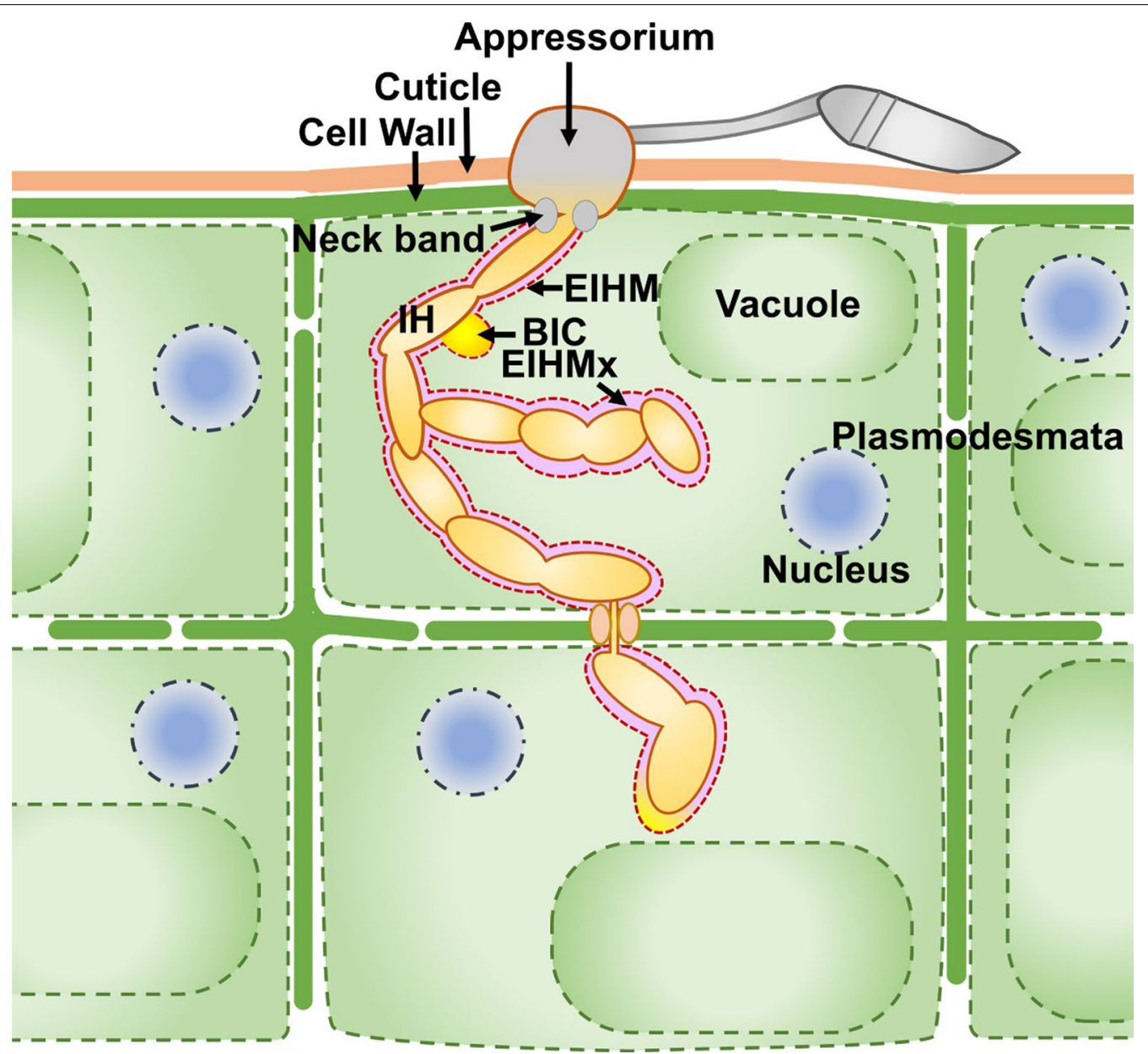

Fig. 2 The infection strategy of M. oryzae. The spore of the fungi germinates and generates an appressorium. The appressorium penetrates the barriers of cuticle and cell wall, extending the invasive hyphae $(\mathrm{IH})$, invaginating the plant plasma membrane. This plant plasma membrane covering the $\mathrm{IH}$ is known as the extrainvasive hyphal membrane (EIHM) and the matrix between the plant and fungal plasma membranes forms the extrainvasive hyphal matrix (EIHMx). The first bulbous IH forms in the biotrophic invasion complex (BIC), which is the specialised region of EIHMx for fungal secretions. ElHMx forms the interface for interactions between the plant and fungi. The fungal IH continue to grow in the plant invading new cells and forming new BIC regions through plasmodesmata

Eseola et al. 2021). This secretion of a repertoire of effectors in a co-ordinated manner and with spatio-temporal dynamics plays a major role in $M$. oryzae infection.

\section{Apoplastic Effectors: 'The Players at the Periphery'}

The effectors that remain in and are targeted to plant apoplast are known as apoplastic effectors. The apoplastic effectors follow a classical Golgi-dependant secretory pathway, which is sensitive to treatment by Brefeldin A (BFA). The apoplastic effectors are mostly localised in the extrainvasive hyphal matrix (EIHMx) lining the fungal cell (Giraldo et al. 2013) (Fig. 3). For example, among the apoplastic effectors, the biotrophy associated secreted (BAS) proteins have been described, which are a class of small cysteine-rich secreted proteins (Giraldo et al. 2013), some of which have been shown to localise in the EIHMx as well as at cell wall crossing points of IH (Mosquera et al. 2009; Khang et al. 2010).

Among the apoplastic effectors of $M$. oryzae, one functionally well-described effector is the secreted LysM (lysine motif) protein 1 (SLP1). Being an apoplastic effector, SLP1 accumulates in the EIHMx and competes with the rice pattern recognition receptor protein LysM protein, chitin elicitor binding protein (OsCE$\mathrm{BiP})$, to bind chitin oligosaccharides and suppress chitin-induced immunity (Mentlak et al. 2012; Giraldo et al. 2013). Another apoplastic effector found to be competing with the OsCEBiP is MoAa91, a M. oryzae 


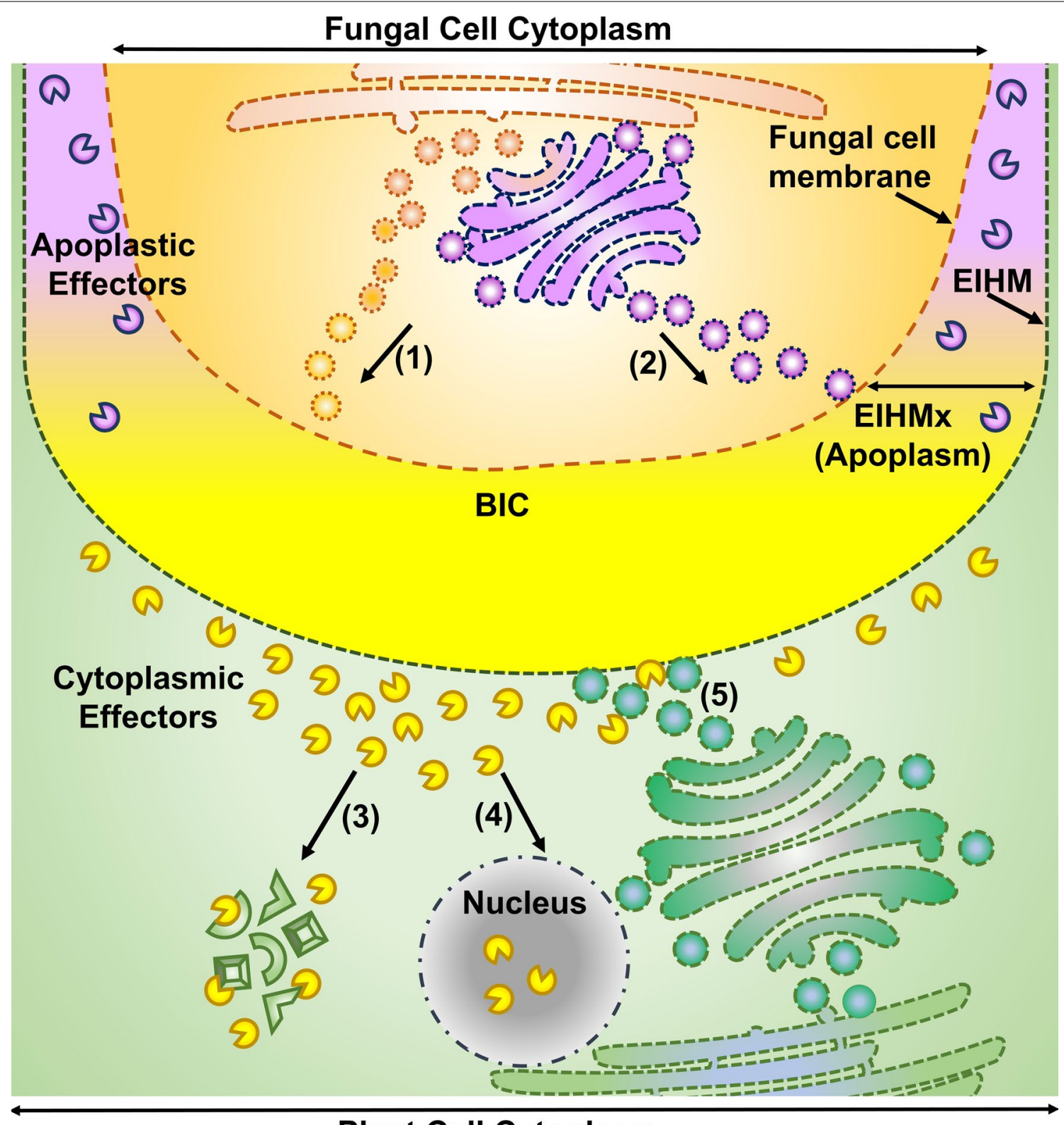

\section{Plant Cell Cytoplasm}

Fig. 3 Effector secretory routes of M. oryzae. The fungal effector secretion takes place via vesicles and follows two routes. The BFA-insensitive vesicle secretion from endoplasmic reticulum (ER) which forms the BIC (1), which is destined for the plant cell cytoplasm, and the BFA-sensitive effector secretion, via Golgi apparatus, which is directed to the EIHMx (2). The effectors secreted to the EIHMx are the apoplastic effectors (violet pie shapes) and secretions from BIC are the cytoplasmic effectors (yellow pie shapes). The cytoplasmic effectors further localise to specific cell compartments such as the nucleus or plasmodesmata (3) or bind their target proteins (4), or have enzymatic activity, to compromise the plant cell and enable fungal growth. The plant cell cytoplasm is shown in green, bright yellow region represents BIC and BIC along with violet represents EIHMx or apoplasm

homolog of the auxiliary activity family 9 protein (Aa9) (Li et al. 2020).
Cytoplasmic Effectors: 'The Internal Intruders'

The cytoplasmic effectors have primarily been shown to be secreted and concentrated at the BIC and are eventually translocated to the plant cell cytoplasm. Some of the cytoplasmic effectors are also known to translocate 
into neighbouring cells via plasmodesmata (Khang et al. 2010). The cytoplasmic effectors follow a Golgi- independent secretory pathway involving the exocyst (Exo70 and Sec5) and t-SNARE (Sso1) complexes, via the endoplasmic reticulum. Hence, cytoplasmic effector secretion is BFA-insensitive (Giraldo et al. 2013) (Fig. 3).

Some examples include PWL2, Avr-Piz-t, and some BAS proteins (Mosquera et al. 2009; Khang et al. 2010). The cytoplasmic effector BAS107 has been shown to localise to the plant cell nucleus, suggesting a compartmental specialisation for the effectors. BAS1 and BAS2 were shown to preferentially localise to the BIC (Mosquera et al. 2009), and BAS107 and BAS1 translocated to uninvaded neighbouring plant cells via plasmodesmata (Khang et al. 2010). Among the small glycine-rich PWL (Pathogenicity toward Weeping Lovegrass) proteins, the cytoplasmic PWL1 and PWL2 have been shown to accumulate at the BIC, and PWL2 has been demonstrated to move from cell-to-cell via plasmodesmata (Sweigard et al. 1995; Kang et al. 1995; Khang et al. 2010).

One of the functionally well-characterised cytoplasmic effectors is Avr-Piz-t, which has been shown to interact with multiple proteins in the host (Li et al. 2009). AvrPiz-t has been shown to interact with a RING-domain E3 ubiquitin ligase, Avr-Piz-t Interacting Protein 6 (APIP6). The interaction leads to the ubiquitination of Avr-Piz-t and degradation of both Avr-Piz-t and APIP6, resulting in the suppression of PAMP-triggered immunity and increased susceptibility of rice (Park et al. 2012). The $R$ gene, Piz-t, surprisingly does not have any direct interaction with the effector. Meanwhile, Piz-t is targeted for degradation by a second RING-domain E3 ubiquitin ligase, APIP10. APIP10 also interacts with Avr-Piz-t leading to its ubiquitination and degradation of both APIP10 and Avr-Piz-t. This degradation of APIP10 leads to stabilization of Piz-t and initiation of ETI (Park et al. 2016). The interaction of Avr-Piz-t with a bZIP transcription factor, APIP5, suppresses the function of APIP5 to promote effector-triggered necrotrophic cell death in rice (Wang et al. 2016a). A virulence target of Avr-Piz-t is the protein APIP12, a homologue of nucleoporin protein, Nup80, with which it interacts and reduces the basal resistance against $M$. oryzae (Tang et al. 2017). APIP4, a Bowman-Birk-type trypsin Inhibitor (BBI), interacts with Avr-Piz-t leading to a reduction in its trypsin inhibitor activity (Zhang et al. 2020). Avr-Piz-t also interacts with the Potassium $\left(\mathrm{K}^{+}\right)$channel protein OsAKT1, to suppress the rice innate immunity (Shi et al. 2018), and with the rice homologue of human small GTPase, OsRac1, to suppress the reactive oxygen species (ROS) production by the host (Bai et al. 2019).

Like Avr-Piz-t, another cytoplasmic effector Avr-Pii also interacts with more than one host protein and plays distinct roles in promoting pathogenesis. The interaction of rice exocyst complex protein OsExo70-F3 with AvrPii is necessary for immunity triggered by the cognate $\mathrm{R}$ protein, Pii (Fujisaki et al. 2015). Like other cytoplasmic effectors, Avr-Pii accumulates at the BIC and in rice cells, it interacts and inhibits the rice NADP-malic enzyme2 (Os-NADP-ME2). Inhibition of Os-NADP-ME2 reduces the NADPH levels, reducing the host ROS burst (Singh et al. 2016).

A family of structurally conserved fungal effectors has been described to share a conserved six $\beta$-sandwich structures with no significant sequence similarity. These effectors were named as MAX-effectors (Magnaporthe Avrs and ToxB-like), and include Avr-CO39, Avr-Pia, Avr-Piz-t, and ToxB (an effector of the wheat tan spot pathogen) (de Guillen et al. 2015). The Avr-CO39 effector has been shown to localise to the endoplasmic reticulum in the rice protoplast (Ribot et al. 2013), and is recognised by the NB-LRR protein pair, RGA4 \& RGA5 (R-gene analog), which also recognize Avr-Pia. Both AvrCO39 and AvrPia were shown to bind RGA5 (Cesari et al. 2013).

M. oryzae effectors have been found to affect multiple hormone signalling pathways as well. The $M$. oryzae hypothetical effector, MoHEG16 was shown to be necessary for the suppression of cell death caused by $M$. oryzae necrosis- and ethylene-inducing protein 1 (Nep1)-like proteins (MoNLPs) (Mogga et al. 2016). The interaction of $M$. oryzae cytoplasmic effector NIS1 with the rice receptor like kinase, OsBAK1, inhibits the kinase activity to suppress PTI (Irieda et al. 2019). IUG6 and IUG9 were identified as novel effectors, among other candidate genes in a new isolate of $M$. oryzae, showing a BIC localisation and suppression of salicylic acid and ethylene signalling (Dong et al. 2015).

Other than functional proteins, various metabolites or hormones have been shown to support the infection of $M$. oryzae. The enzyme, antibiotic biosynthesis monooxygenase (Abm), was shown to convert free jasmonic acid (JA) to Hydroxylated JA (12OH-JA), which helps the fungus to evade the rice immune responses. Abm localises to the fungal endoplasmic reticulum and $\mathrm{BIC}$, indicating that $\mathrm{Abm}$ could be a secreted protein. Thus, both fungal derived enzymes and products of their activity together impart their action as effectors (Patkar et al. 2015). The avirulence conferring enzyme 1 (ACE1), an appressorialocalised effector protein, produces a secondary metabolite, which is the effector rather than the protein itself (Bohnert et al. 2004; Collemare et al. 2008). Like ACE1, the TAS1 enzyme has been shown to produce the wellcharacterised mycotoxin Tenuazonic acid (TeA) (Yun et al. 2015). Similarly, another enzyme, cytokinin synthesis 1 , CSK1, was shown to be involved in active cytokinin 
production by $M$. oryzae. The cytokinin from fungus was shown to be involved in increasing metabolic availability, reducing defense responses and altering gene expression, thus suggesting that the cytokinin secreted by $M$. oryzae could be a classical effector (Chanclud et al. 2016). These studies implicate that the fungal secondary metabolites function as effectors and play key roles in disease progression. Table 3 summarises all the discussed M. oryzae effectors.

\section{Insect Pests}

Rice is infested by a wide range of insect pests. The major insect pests include planthoppers, namely brown planthopper (BPH; Nilaparvata lugens), whitebacked planthopper (WBPH; Sogatella furcifera), smaller brown planthopper (SBPH; Laodelphax striatellus) and green rice leafhopper (GRH; Nephotettix cincticeps). Stemborers and Asian rice gall midge (Orseolia oryzae) are other major pests of rice (Bentur et al. 2016). Apart from damaging the crop by ingesting the phloem sap, many of these insects also transmit viruses that cause diseases in rice (Huang et al. 2019b).

Different insects have different ways of obtaining their food. Among the piercing-sucking insects, BPH shows intracellular probing while GRH shows intercellular probing (Sōgawa 1982). The chewing insects access nutrients by causing mechanical damage to the host, whereas in piercing-sucking insects, the insect saliva forms the interface between the host and the insect. It has been shown that the insect saliva is composed of a diverse array of molecules. Majority of the studies on riceinsect interactions have been carried out with respect to the piercing-sucking insects like $\mathrm{BPH}$ and GRH. These insects probe the host tissue using their stylets in order to find a proper feeding site (Fig. 4). During this process, they secrete two types of saliva, the gelling saliva and the watery saliva. The gelling saliva is believed to aid in the production of a salivary sheath that might be helpful in providing mechanical strength to the stylet of the insect. Watery saliva is secreted into the plant tissue and might play a role in establishing proper conditions for accessing the nutrients, as has been established by various studies (Huang et al. 2019b). Hence, insect saliva is becoming an attractive area of study. Studies on plant- aphid interactions have demonstrated that the salivary components of the insect have the ability to alter the host physiology and also elicit the host response against the insect attack (Rodriguez and Bos 2013; Elzinga and Jander 2013).

Until now, many studies have demonstrated the global profile of the secretome of insects that attack rice, including $\mathrm{BPH}, \mathrm{WBPH}$, and GRH. Transcriptomics and proteomics approaches were used to profile the salivary gland transcriptome and the insect secretome, respectively. This section summarises these findings.

\section{Insect Saliva: A Repertoire of Diverse Set of Molecules}

The role of insect saliva in the plant-insect interface has been known since the 1960s (Sogawa 1967). Studies on plant-insect interaction have revealed the ability of the insect saliva or oral secretions to induce and alter the host defense response (Rodriguez and Bos 2013; Acevedo et al. 2015). In rice, it was shown that the application of salivary gland extract of BPH causes rice transcriptional changes (Petrova and Smith 2015). Also, oral secretion of two chewing insects, viz., Mythimna loreyi and Parnara guttata were shown to elicit immune responses in rice (Shinya et al. 2016). These studies suggest that the salivary components of insects have the ability to alter the host physiology. Most of the studies in rice have been carried out with respect to the rice-planthopper interaction. Such studies have analysed the transcriptome or secretome of the insect salivary glands or saliva, respectively.

Transcriptomics studies of the salivary glands of $\mathrm{BPH}$ and GRH have established the global profile of the genes that are expressed in the insect salivary glands. Two different studies have identified 352 and 76 genes that encode secretory proteins in BPH and GRH, respectively (Ji et al. 2013; Matsumoto et al. 2014). Results from both these studies suggest that there are a large number of proteins that are salivary gland-secreted, which function as enzymes. Among various predicted genes, those coding for serine protease, disulfide isomerase, lipase, and dehydrogenase were common with other piercingsucking insects. In addition, the same study found that 45 out of the 68 salivary gland-specific transcripts code for unknown proteins (Matsumoto et al. 2014).

Other predicted genes encode for plant cell wall degrading enzymes, $\beta$-glucanases, $\beta$-glucosidases, glycosylases, trypsin-like proteins, lipases and $\alpha$-amylase. Besides enzymes, genes encoding chemosensory proteins (CSPs) and odorant-binding proteins (OBPs) were also identified. It was previously shown in other systems that, CSPs and OBPs have host physiology altering ability (Ji et al. 2013). In addition, Ji et al. (2013) had identified a set of 67 salivary gland genes that are differentially expressed between two biotypes of BPH that differ in virulence. Another transcriptomics study identified 19 secretory proteins that might play a role in plant defense suppression and detoxification and digestion of the plant cell wall (Miao et al. 2018a).

Proteomics studies were crucial in establishing the truly secreted components of insect saliva. Approaches like 2D-PAGE and LC-MS/MS were used to study the 
Table 3 Effectors of M. oryzae

\begin{tabular}{|c|c|c|}
\hline Effector & Known function/related information & References \\
\hline \multicolumn{3}{|l|}{ Apoplastic effectors } \\
\hline SLP1 & $\begin{array}{l}\text { Competes with plant OsCEBiP to bind chitin oligosaccharides } \\
\text { and helps the fungus suppress chitin-induced immunity in host; } \\
\text { outlines IH, i.e. localised to ElHMx }\end{array}$ & Mentlak et al. (2012), Giraldo et al. (2013) \\
\hline BAS3 & $\begin{array}{l}\text { focused point localisation in EIHMx \& accumulates in the } \\
\text { regions where } I H \text { cross at the cell wall to neighbouring cells }\end{array}$ & Mosquera et al. (2009) \\
\hline BAS4 & 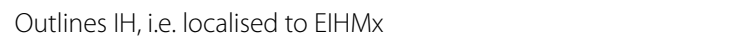 & Mosquera et al. (2009) \\
\hline BAS113 & Outlines $I H$, i.e. localised to EIHMx & Giraldo et al. (2013) \\
\hline MC69 & Targeted gene disruption affects the pathogenicity of M. oryzae & Saitoh et al. (2012) \\
\hline MSP1 & $\begin{array}{l}\text { Secreted into apoplasm; induces cell death \& elicits immune } \\
\text { responses }\end{array}$ & Wang et al. (2016C) \\
\hline \multicolumn{3}{|l|}{ Cytoplasmic effectors } \\
\hline PWL1 & Accumulate at BIC, translocate to rice cytoplasm & Khang et al. (2010) \\
\hline PWL2 & $\begin{array}{l}\text { Accumulate at BIC, translocate to rice cytoplasm, and move } \\
\text { from cell to cell }\end{array}$ & Khang et al. (2010) \\
\hline BAS1 & Accumulate at BIC & Khang et al. (2010), Mosquera et al. (2009) \\
\hline BAS2 & $\begin{array}{l}\text { Translocate to rice cytoplasm, and accumulate at cell wall cross- } \\
\text { ing points }\end{array}$ & Mosquera et al. (2009) \\
\hline BAS107 & $\begin{array}{l}\text { Accumulates at BIC, translocates and localises to rice cell } \\
\text { nucleus, also moves from cell to cell }\end{array}$ & Giraldo et al. (2013) \\
\hline Avr-Piz-t & $\begin{array}{l}\text { Translocates to rice cells; interacts with Avr-Piz-t Interacting } \\
\text { Protein } 6 \text { (APIP6, RING E3 ubiquitin ligase), APIP10 (RING E3 } \\
\text { ubiquitin ligase), APIP5(bZIP transcription factor), APIP12 (homo- } \\
\text { logue of nucleoporin protein, Nup80), OsAKT1 (Potassium } \\
\left(\mathrm{K}^{+}\right) \text {channel protein) and OsRac1 (homologue of human small } \\
\text { GTPase) to suppress PTI }\end{array}$ & $\begin{array}{l}\text { Park et al. (2012, 2016), Wang et al. (2016a), } \\
\text { Tang et al. (2017), Shi et al. (2018), Bai et al. } \\
\text { (2019) }\end{array}$ \\
\hline Avr-Pii & $\begin{array}{l}\text { Interact with OsExo70-F3 (exocyst complex protein) and } \\
\text { Os-NADP-ME2 (NADP-malic enzyme2) }\end{array}$ & Fujisaki et al. (2015), Singh et al. (2016) \\
\hline Avr-CO39 & $\begin{array}{l}\text { Translocates to rice cells; purified protein directly localises to } \\
\text { protoplast without aid from fungal components, RAG5 interac- } \\
\text { tion leads to recognition by RAG4/RAG5 R pair proteins }\end{array}$ & Ribot et al. (2013), Cesari et al. (2013) \\
\hline Avr-Pia & $\begin{array}{l}\text { RAG5 interaction leads to recognition by RAG4/RAG5 R pair } \\
\text { proteins }\end{array}$ & Cesari et al. (2013) \\
\hline MoHEG13 & Suppresses the cell death caused by MoNLP proteins & Mogga et al. (2016) \\
\hline MoHEG16 & Necessary for successful virulence of $M$. oryzae & Mogga et al. (2016) \\
\hline IUG6 & $\begin{array}{l}\text { BIC localisation and suppression of salicylic acid \& ethylene } \\
\text { signalling }\end{array}$ & Dong et al. (2015) \\
\hline IUG9 & $\begin{array}{l}\text { BIC localisation and suppression of salicylic acid \& ethylene } \\
\text { signalling }\end{array}$ & Dong et al. (2015) \\
\hline Avr-Pita & $\begin{array}{l}\text { Predicted metalloprotease domain; binds to cognate R protein } \\
\text { Pita directly; accumulates at BIC }\end{array}$ & Jia et al. (2000) \\
\hline Avr-Pik/km/kp & $\begin{array}{l}\text { The different alleles are pathogen race specific; have cognate } \\
\text { functional R gene pair of NB-LRR with a set of Pik alleles in rice }\end{array}$ & Yoshida et al. (2009), Kanzaki et al. (2012) \\
\hline Avr-Pi9 & Localises to BIC and translocate to rice cells & Wu et al. (2015) \\
\hline Avr-Pib & & Zhang et al. (2015) \\
\hline Avr-Pi54 & Interacts directly with the $\mathrm{R}$ protein $\mathrm{Pi} 54$ & Devanna et al. (2014) \\
\hline Avr-Pi12 & & Li et al. (2018b) \\
\hline \multicolumn{3}{|l|}{ Secondary metabolites as effector } \\
\hline Hydroxylated Jasmonic acid (12OH-JA) & $\begin{array}{l}\text { antibiotic biosynthesis monooxygenase }(\mathrm{Abm}) \text { converts free } \\
\text { jasmonic acid }(J \mathrm{~A}) \text { to Hydroxylated } J \mathrm{~A}(12 \mathrm{OH}-\mathrm{JA})\end{array}$ & Patkar et al. (2015) \\
\hline Unknown secondary metabolite & $\begin{array}{l}\text { Synthesis involves avirulence conferring enzyme 1, ACE1 an } \\
\text { appressoria localised effector protein; the corresponding R gene } \\
\text { is identified to be Pi33 }\end{array}$ & Bohnert et al. (2004), Collemare et al. (2008) \\
\hline Tenuazonic acid (TeA) & TAS1 is involved in the synthesis of TeA & Yun et al. (2015) \\
\hline Cytokinin & Known protein involved is cytokinin synthesis 1, CSK1 & Chanclud et al. (2016) \\
\hline
\end{tabular}


insect saliva. All these studies used the saliva secretions of insects that were fed on artificial diet. In common, all the studies identified a wide variety of enzymes and proteins with diverse functions to be present in the saliva of BPH, WBPH, and GRH (Konishi et al. 2009; Liu et al. 2016; Huang et al. 2016; Hattori et al. 2015; Miao et al. 2018b). Proteins involved in $\mathrm{Ca}^{2+}$-binding, ATP-binding, cytoskeletal, DNA- or RNA-binding, chromatin binding, transporters, apolipoproteins, ubiquitin, and heat shock proteins were also identified in the saliva (Liu et al. 2016). Details of the studies are shown in Table 4. These studies have established the components of insect saliva and laid the foundation for further studies on the molecular aspects of plant-insect interaction.

\section{Insect Effectors: The Players at the Interface}

Knockdown of insect genes using dsRNA has proved to be a valuable approach for functional characterisation of genes (Gu and Knipple 2013). Certain salivary proteins were found to be essential for the fitness of the insect. Knockdown of BPH NlMul (Nilaparvata lugens Mucinlike protein) has resulted in short and single-branched stylets. NlMul gene codes for a mucin-like protein that is present in abundance in the insect saliva. Mucins are highly glycosylated proteins and are important for the cell-environment communication (Huang et al. 2017). Knockdown of another salivary protein-encoding gene in $\mathrm{BPH}, \mathrm{NlSh}$ (Nl Sheath protein) was shown to inhibit the formation of salivary flanges and salivary sheath. NIShp was annotated as an unknown protein (Huang et al. 2015). Another study revealed that three protein coding genes, including an annexin-like protein (ANX-like 5 ), a salivary sheath protein (salivap-3) and a carbonic anhydrase $(C A)$, are essential for the survival of $\mathrm{BPH}$ in rice. Further $A N X$-like 5 and salivap-3 were shown to be indispensable for the feeding behaviour of BPH wherein the knockdown of these genes showed negative effects on phloem sap-feeding time and honeydew excretion by BPH (Huang et al. 2016). These studies support the notion that proper salivary sheath formation is essential for BPH virulence in rice. In GRH, knockdown of NcSP75, (Nephotettix cincticeps Salivary Protein $75 \mathrm{kDa}$ ) encoding a salivary protein of unknown function, was shown to cause poor performance of the insect on rice, while no such effects were seen in insects raised on artificial diet (Matsumoto and Hattori 2018). As the knockdown of these genes led to lesser virulence of the insect, it is possible that these gene products aid in the interaction between the host and the pest.

In order to reach the vascular bundle, the insect uses its stylet to probe and pierce through the plant tissue. During this process, the insect has to break the cell wall components of the plant cell. The expression of genes coding for plant cell wall degrading proteins in the $\mathrm{BPH}$ salivary gland was described previously (Ji et al. 2013). $N l E G 1$, a predicted endo- $\beta-1,4$-glucanase, was shown to have in-vitro endoglucanase activity and the knockdown of NlEG1 reduced the insect's ability to reach the phloem and also had negative impacts on food intake, mass, survival, and fecundity of the insect on rice plants. Additionally, only a small effect on survival was seen in the insects that were raised on artificial diet. Hence, it is speculated that NIEG1 might act as an effector which alters the host structures and enables the stylet to reach the phloem (Ji et al. 2017).

Further, catalase gene named Kat-1 was shown to be secreted into the rice tissue and possess catalase activity (Petrova and Smith 2014). It is speculated that Kat-1 might be helpful in scavenging the hydrogen peroxide $\left(\mathrm{H}_{2} \mathrm{O}_{2}\right)$ molecules released by the plant post insect attack. A mucin-like protein, NIMLP was also shown to be important for insect performance and salivary sheath formation. In addition, NIMLP was found to induce cell death when transiently expressed in either rice protoplasts or Nicotiana benthamiana leaves. The induction of cell death was found to be calcium-dependent and acting through the MEK2-dependent MAPK pathway. Also, NIMLP was shown to induce callose deposition and trigger jasmonic acid-related defense gene expression in $N$. benthamiana (Shangguan et al. 2018).

Calcium signalling is known to be an immediate response by plants after insect attack. It results in the occlusion of sieve elements, thereby preventing the insects from ingesting the sap (Rodriguez and Bos 2013). But the insects are mostly successful in overcoming this block. Studies had shown that insect saliva possesses $\mathrm{Ca}^{2+}$-binding proteins. NISEF1 is an EF-hand $\mathrm{Ca}^{2+}$-binding protein present in the saliva of $\mathrm{BPH}$ and is secreted into the rice tissue. Also, it was shown that NISEF1 reduces the cytosolic $\mathrm{Ca}^{2+}$ levels in rice and suppresses wound-induced $\mathrm{H}_{2} \mathrm{O}_{2}$ production. Moreover, the knockdown of NISEF1 decreased the survival and feeding of the insects (Ye et al. 2017). A similar protein was also characterised in GRH. NcSP84 was found to be a

(See figure on next page.)

Fig. 4 Schematic representation of BPH-Rice interaction. Using its stylet, the insect pierces the rice tissue and reaches the phloem to suck the sap. During this process, both gelling and watery saliva are secreted by the insect, which contain various molecules that elicit or act against plant defense. Proteins like catalase, endoglucanase, and $\mathrm{Ca}^{2+}$-binding proteins might be involved in suppressing the plant defense while proteins like Mucin-like proteins, Apolipophorins, and Protein disulfide isomerase elicit immune responses. Some of these proteins were found to induce callose deposition, cell death and SA or JA- associated defense gene expression 


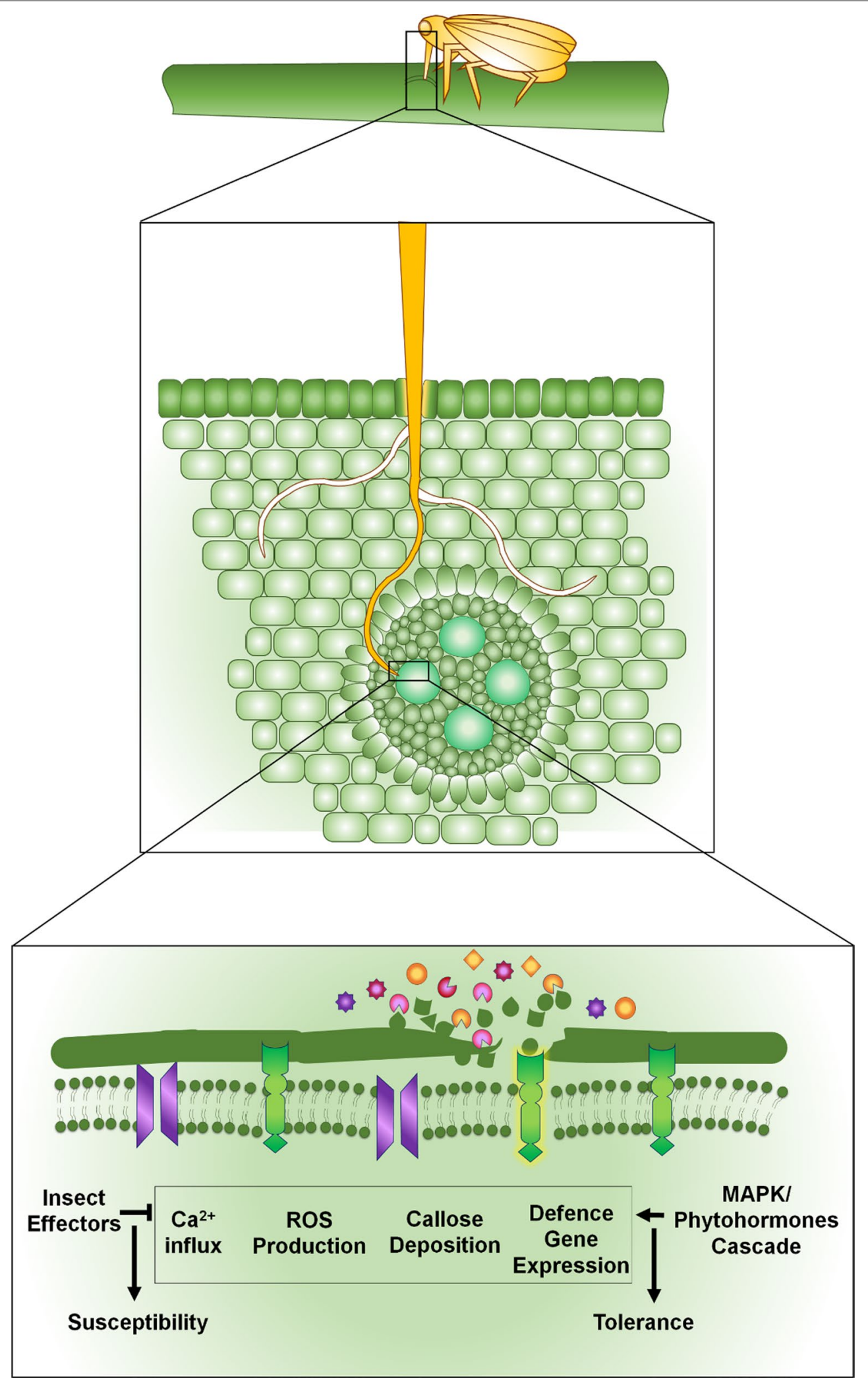

Fig. 4 (See legend on previous page.) 
Table 4 Studies that established the secretome of various rice pests

\begin{tabular}{lllll}
\hline Insect & Source material & Approach & Number of proteins/genes identified & References \\
\hline BPH & SG & $\begin{array}{l}\text { 2D-PAGE and Edman } \\
\text { Degradation }\end{array}$ & 52 proteins & Konishi et al. (2009) \\
BPH & Secreted Saliva & LC-MS/MS & 202-Watery Saliva Proteins & Huang et al. (2016) \\
& Secreted Saliva & LC-MS/MS & 18 -Gelling Saliva Proteins & Liu et al. (2016) \\
BPH & SG & Transcriptome & 1140 genes coding secretory proteins & Rao et al. (2019) \\
BPH & SG & Transcriptome & 352 genes coding secretory proteins & Ji et al. (2013) \\
BPH & SG & Transcriptome & 19 -SG Specific secreted protein encoding genes & Miao et al. (2018a) \\
GRH & Secreted Saliva & LC-MS/MS & 71 - Proteins & Hattori et al. (2015) \\
GRH & SG & Transcriptome & 76 genes coding secretory proteins & Matsumoto et al. (2014) \\
WBPH & Secreted Saliva & LC-MS/MS & 161 -Watery saliva proteins & Miao et al. (2018b) \\
\hline
\end{tabular}

BPH Brown planthopper, GRH Green rice leafhopper, WBPH Whitebacked planthopper, LC MS/MS Liquid Chromatography-Tandem Mass Spectrometry, SG salivary gland, 2D-PAGE two-dimensional polyacrylamide gel electrophoresis

salivary protein that exhibits in-vitro $\mathrm{Ca}^{2+}$-binding activity and is secreted into the rice tissue (Hattori et al. 2012). The putative effectors thus far identified have been tabulated in Table 5. These studies support the possible role of insect-associated molecules in suppressing the plant defense response.
In order to identify the effector properties of a candidate protein, transient transformation of $N$. benthamiana followed by cell death assays is widely used. Using such a strategy, six putative effectors were identified in $\mathrm{BPH}$ after screening 64 candidates. The six putative effectors include protein disulfide isomerase (PDI; N112), apolipophorin (N116), small secreted cysteine-rice protein

Table 5 Insect associated molecules that are characterised

\begin{tabular}{|c|c|c|c|c|}
\hline Insect & Protein & Description & Activity and localisation in rice & References \\
\hline $\mathrm{BPH}$ & NIMLP & Mucin-like protein & $\begin{array}{l}\text { Cell death and callose deposition } \\
\text { Cytoplasm }\end{array}$ & Shangguan et al. (2018) \\
\hline $\mathrm{BPH}$ & NISEF1 & EF-hand $\mathrm{Ca}^{2+}$-binding protein & $\begin{array}{l}\text { Suppression of wound-induced } \mathrm{H}_{2} \mathrm{O}_{2} \text { and reduction in } \\
\text { cytosolic } \mathrm{Ca}^{2+} \text { level }\end{array}$ & Ye et al. (2017) \\
\hline $\mathrm{BPH}$ & NIEG1 & endo- $\beta$-1,4-glucanase & Possesses in vitro endoglucanase activity & Ji et al. (2017) \\
\hline $\mathrm{BPH}$ & NIMul & Mucin-like protein & - & Huang et al. (2017) \\
\hline $\mathrm{BPH}$ & Kat-1 & Catalase & In vitro catalase activity & Petrova and Smith, (2014) \\
\hline $\mathrm{BPH}$ & salivap-3 & Salivary Protein & - & Huang et al. (2016) \\
\hline $\mathrm{BPH}$ & CA & Carbonic Anhydrase & - & Huang et al. (2016) \\
\hline $\mathrm{BPH}$ & ANX-like 5 & Annexin-like protein 5 & - & Huang et al. (2016) \\
\hline $\mathrm{BPH}$ & $\mathrm{N} 112$ & Protein disulfide isomerase & Cell death/Nucleo-cytoplasmic & Rao et al. (2019) \\
\hline $\mathrm{BPH}$ & N116 & Apolipophorin-III & Cell death/Nucleo-cytoplasmic & Rao et al. (2019) \\
\hline $\mathrm{BPH}$ & N128 & Small secreted cysteine-rich protein & Cell death/Nucleo-cytoplasmic & Rao et al. (2019) \\
\hline $\mathrm{BPH}$ & N132 & Chemosensory protein & Nucleo-cytoplasmic & Rao et al. (2019) \\
\hline $\mathrm{BPH}$ & N140 & Unknown Protein & - & Rao et al. (2019) \\
\hline $\mathrm{BPH}$ & N143 & Unknown protein & Cell death/Nucleus & Rao et al. (2019) \\
\hline $\mathrm{GRH}$ & NcSP75 & Unknown Protein & - & Matsumoto and Hattori, (2018) \\
\hline $\mathrm{GRH}$ & NcSP84 & EF-hand $\mathrm{Ca}^{2+}$-binding protein & In vitro $\mathrm{Ca}^{2+}$ binding activity & Hattori et al. (2012) \\
\hline GRH & $\beta$-glucosidase & $\beta$-glucosidase & In vitro hydrolysis of p-nitrophenyl-b-D-glucopyranoside & Nakamura and Hattori, (2013) \\
\hline $\mathrm{GRH}$ & NcLac1S & Laccase & In vitro laccase activity & Hattori et al. (2010) \\
\hline $\mathrm{SBPH}$ & DNasell & Deoxyribonuclease II & $\begin{array}{l}\text { In vitro DNAse activity; suppression of insect-induced } \\
\text { callose and } \mathrm{H}_{2} \mathrm{O}_{2} \text { accumulation }\end{array}$ & Huang et al. (2019a) \\
\hline RGM & OoNDPK & Nucleoside diphosphate kinase & $\begin{array}{l}\text { Secreted into the host cells; causes elongation of rice } \\
\text { coleoptile cells }\end{array}$ & Sinha et al. (2012) \\
\hline
\end{tabular}


(SSCP; N128), chemosensory protein (CSP; N132), and two proteins with no predicted functions (N140 and N143). These proteins were found to induce cell death, chlorosis, or dwarf phenotype in $N$. benthamiana. In addition, the proteins also induced defense responses including callose deposition and defense gene expression (Rao et al. 2019). Cellular damage could occur during the penetration of insect stylet which in turn would result in the release of cellular components. The presence of deoxyribonucleic acid (DNA) in the extracellular region is also known to trigger plant defense responses by acting as a damage-associated molecular pattern (DAMP) (Quintana-Rodriguez et al. 2018). Previous studies have reported the presence of deoxyribonuclease II (DNase II) in the saliva of planthoppers (Liu et al. 2016; Miao et al. 2018b). The DNase II in small brown planthopper saliva suppresses induction of plant defense responses including $\mathrm{H}_{2} \mathrm{O}_{2}$ accumulation and callose deposition. In addition, it was shown that the exogenous application of DNase II slightly reduced those responses (Huang et al. 2019a).

Another pest, the rice gall midge (RGM), causes gall formation in susceptible rice varieties and is a major threat for crop production. RGM induces gall formation in rice apical meristem by altering the rice metabolic pathways in order to facilitate its own survival (Sinha et al. 2011). Although a serious pest of rice, the studies on the pest effectors that are involved in establishing gall formation are somewhat limited. In one study, gene expression analysis of RGM maggots identified a nucleotide diphosphate kinase (NDPK), that is highly expressed in compatible interaction than in incompatible interaction (Sinha et al. 2012). NDPK was identified to be secreted into rice during RGM feeding and the application of recombinant NDPK resulted in the elongation of rice coleoptile cells. This study suggested a possible role of NDPK in facilitating the alteration of host machinery to establish gall formation by RGM.

Many rice resistance genes have been identified against the major rice pests including the planthoppers and the gall midge. Like many disease resistance genes, the insect resistance genes also encode Nucleotide binding-siteLeucine rich repeat-containing proteins (NBS-LRRs), among others (Bentur et al. 2016; Fujita et al. 2013). This suggests that a direct recognition of the pest-associated molecules may be occuring in the cytoplasm of plant cells.

\section{Conclusions: Diverse Attackers-Common Pathways}

The pathogens and pests discussed in this review represent a diverse group of organisms but with rice as a common host. The first striking difference between the different pathogens and pests is the mode of effector secretion. In bacteria, dedicated type II and type III secretion systems are involved in the secretion of effector proteins, whereas fungal pathogens employ the BFA- sensitive or BFA- insensitive vesicular pathways for effector secretion (Jha et al. 2007; Giraldo et al. 2013). Insects, on the other hand, secrete saliva, which contains the complete repertoire of effectors (Shangguan et al. 2018). Pathogenesis begins by the invasion of the plant cell. This is accomplished by the apoplastic effectors, which breach the plant cell wall and facilitate entry into the host cellular system. Most of these apoplastic effectors have defined enzymatic activity, the majority of which are directed towards disruption of cell wall barriers leading to nutrient availability (Ji et al. 2013, 2017; Jha et al. 2005; Tayi et al. 2016b; Rajeshwari et al. 2005; Aparna et al. 2009; Zou et al. 2012).

However, for suppression of plant immune responses, these different pathogens and pests seem to target common nodes in plant defense. Some of the common pathways targeted by the pathogens and pests include well-characterised immune response components, such as the MAPK pathway, ubiquitination pathway, calcium signalling, and hormone signalling. For example, both bacterial peptidoglycan and fungal chitin are recognised by the OsCERK1 receptor complex, which further phosphorylates the cytoplasmic receptor kinase OsRLCK185 and activates MAPK cascades (Akamatsu et al. 2013; Wang et al. 2017; Yamaguchi et al. 2013b; Ao et al. 2014). This seems to be a critical step in the induction of defense responses against multiple pathogens, and hence is also a target for suppression of immune responses by the pathogens, eg., by $\mathrm{XopY}_{\mathrm{Xoo}}, \mathrm{XopP}_{\mathrm{Xoo}}$, MoSLP1, and Avr-Piz-t (Yamaguchi et al. 2013b; Mentlak et al. 2012; Giraldo et al. 2013; Bai et al. 2019; Ishikawa et al. 2014). The MAPK signalling pathway amplifies the plant immune responses, thus making it another nodal point for suppression. Numerous effector proteins target the MAPK signalling events, hence modulating the plant immune responses (Long et al. 2018; Mentlak et al. 2012; Giraldo et al. 2013). In parallel, some of the pathways which are activated early on during pathogen infection and pest infestation include calcium signalling and the oxidative burst (Akamatsu et al. 2013), which pathogens and pests have evolved to suppress in order to cause infection (Giraldo et al. 2013; Mentlak et al. 2012; Bai et al. 2019; Singh et al. 2016). For instance, an effector from BPH, NISEF1, suppresses cytosolic $\mathrm{Ca}^{2+}$ levels and wound-induced $\mathrm{H}_{2} \mathrm{O}_{2}$ (Ye et al. 2017), whereas the Magnaporthe effectors Avr-Piz-t and Avr-Pii were shown to suppress ROS levels (Bai et al. 2019; Singh et al. 2016). Another important molecular cascade that is targeted by pathogens to evade immune activation is regulation via 
ubiquitination, specifically, by targeting the E3 Ubiquitin ligases, which regulate the final step of ubiquitin conjugation (Ishikawa et al. 2014; Park et al. 2016, 2012).

The hormone signalling pathways are important targets for host defense manipulation. Effectors from pathogens and pests modulate components of hormone pathways to suppress the plant defenses. Effectors from Xoo have been shown to suppress immune responses by targeting brassinosteroid signalling (Yamaguchi et al. 2013a; Wang et al. 2008), whereas Magnaporthe effectors modulate cytokinin and active jasmonic acid levels in planta (Chanclud et al. 2016; Patkar et al. 2015).

Yet another common feature among effector proteins is functional compartmentalisation. Some of the bacterial non-TAL effectors as well as the TAL effectors are known to translocate to the nucleus in plant cells. Although the precise functions have not been elucidated for fungal and pest effectors, nuclear localisation is observed, suggesting that nuclear localisation is possibly important for the function of several effectors (Gurlebeck et al. 2006; Mosquera et al. 2009; Giraldo et al. 2013; Deb et al. 2019, 2020; Rao et al. 2019). In bacterial pathogens, some TAL effectors specifically target and regulate gene expression of susceptibility factors like SWEET genes (Yang et al. 2006; Antony et al. 2010; Yuan et al. 2009). This seems to be crucial in Xoo since geographically distant strains of Xoo were shown to upregulate the same or different SWEET genes through different TAL effectors (Streubel et al. 2013).

The primary requirement of the pathogen and pest is immune evasion in order to establish itself in the host. For this, they target multiple pathways in rice. The convergence of effector functions could be attributed in part to the common host pathways which are involved in defense against multiple pathogens and pests. The characterisation of such key components of the plant immune system would lead to a more comprehensive understanding of plant resistance responses to pathogens and pests.

\section{Future Perspectives}

Although numerous studies have been focused on understanding the mechanism of host- pathogen/pest interactions in rice, there is a lot that remains to be explored. Gaps in our knowledge exist regarding the molecular mechanisms of effector action in rice. It is established that different pathotypes of a pathovar or biotypes of an insect possess an effectome repertoire specific for causing disease in a plant genotype in a particular geographical location. How this diversity in effectome and the crosstalk between the effectors helps in disease development remains to be determined. Studies on hub proteins in immune signalling pathways are also crucial to understand immune response functioning. Ultimately, this knowledge should be leveraged to develop crop varieties that are resistant to multiple pathogens and pests, thus helping to meet the increasing demand of global rice production.

\begin{abstract}
Abbreviations
12OH-JA: Hydroxylated JA; 2D-PAGE: Two-dimensional polyacrylamide gel electrophoresis; BAS: Biotrophy associated secreted; BB: Bacterial Blight; BBI: Bowman-Birk-type trypsin Inhibitor; BFA: Brefeldin A; BIC: Biotrophic invasion complex; BLS: Bacterial Leaf Streak; BPH: Brown planthopper; CWDE: Cell Wall Degrading Enzymes; DAMP: Damage-Associated Molecular Pattern; DNA: Deoxyribonucleic acid; ElHM: Extrainvasive hyphal membrane; ElHMx: Extrainvasive hyphal matrix; ETI: Effector triggered immunity; GRH: Green rice leafhopper; IH: Invasive hyphae; JA: Jasmonic acid; LC MS/MS: Liquid Chromatography-Tandem Mass Spectrometry; M. oryzae: Magnaporthe oryzae; NADPH: Nicotinamide adenine dinucleotide phosphate; NBS-LRR: NucleotideBinding Site-Leucine Rich Repeats; PAMP: Pathogen-Associated Molecular Pattern; PGN: Peptidoglycan; pv:: Pathovar; PWL: Pathogenicity toward Weeping Lovegrass; RGA: R-gene analog; R-gene: Resistance gene; RGM: Rice Gall Midge; RNA: Ribonucleic acid; ROS: Reactive oxygen species; SBPH: Small Brown planthopper; SG: Salivary Gland; T2SS: Type 2 Secretion System; T3SS: Type 3 Secretion System; TALE: Transcription-activator like effector; TeA: Tenuazonic acid; WBPH: White-backed planthopper; Xoc: Xanthomonas oryzae pv. oryzicola; Xoo: Xanthomonas oryzae pv. oryzae; Xop: Xanthomonas outer protein
\end{abstract}

\section{Acknowledgements}

We apologize to those authors whose work was omitted or not emphasized due to space limitations.

\section{Authors' contributions}

SD, VNM and GCG wrote the manuscript. HKP and RVS finalized the manuscript, which was approved by all the authors. All authors read and approved the final manuscript.

\section{Funding}

This work was supported by grants to RVS from the Plant-Microbe and Soil Interaction (PMSI) project of the Council of Scientific and Industrial Research (CSIR), Government of India (Project Code: BSC0117) and the J. C. Bose

fellowship to RVS from the Department of Science and Technology (DST), Government of India (Project Code: GAP0444). This work was also supported by grants to HKP from the Council of Scientific and Industrial Research (CSIR), Government of India (Project Code: MLP0121). SD acknowledges the Council of Scientific and Industrial Research (CSIR), Government of India for fellowship. CGG acknowledges the Council of Scientific and Industrial Research (CSIR), Government of India for Ph.D. fellowship. VNM acknowledges Ph.D. scholarship funding from UGC, Govt. of India.

Availability of data and materials

Data sharing is not applicable to this article as no datasets were generated during this study.

\section{Declarations}

Ethics approval and consent to participate

Not applicable.

\section{Consent for publication}

Not applicable.

\section{Competing interests}

The authors declare that they have no competing interests.

\section{Author details}

${ }^{1}$ CSIR-Centre for Cellular and Molecular Biology (CSIR-CCMB),

Hyderabad 500007, India. ${ }^{2}$ Present Address: Department of Plant and Environmental Sciences, University of Copenhagen, 1871 Frederiksberg C, Denmark. 
${ }^{3}$ Present Address: Indian Institute of Science Education and Research (IISER) Tirupati, Tirupati 517507, India.

Received: 13 July 2021 Accepted: 6 November 2021 Published online: 18 November 2021

\section{References}

Acevedo FE, Rivera-Vega LJ, Chung SH, Ray S, Felton GW (2015) Cues from chewing insects - the intersection of DAMPs, HAMPs, MAMPs and effectors. Curr Opin Plant Biol 26:80-86

Ahn IP, Kim S, Lee YH (2005) Vitamin B1 functions as an activator of plant disease resistance. Plant Physiol 138:1505-1515

Ahn IP, Kim S, Lee YH, Suh SC (2007) Vitamin B1-induced priming is dependent on hydrogen peroxide and the NPR1 gene in Arabidopsis. Plant Physiol 143:838-848

Akamatsu A, Wong HL, Fujiwara M, Okuda J, Nishide K, Uno K, Imai K, Umemura K, Kawasaki T, Kawano Y, Shimamoto K (2013) An OsCEBiP/ OsCERK1-OsRacGEF1-OsRac1 module is an essential early component of chitin-induced rice immunity. Cell Host Microbe 13:465-476

Akimoto-Tomiyama C, Furutani A, Tsuge S, Washington EJ, Nishizawa Y, Minami E, Ochiai H (2012) XopR, a type III effector secreted by Xanthomonas oryzae pv. oryzae, suppresses microbe-associated molecular patterntriggered immunity in Arabidopsis thaliana. Mol Plant Microbe Interact 25:505-514

Antony G, Zhou J, Huang S, Li T, Liu B, White F, Yang B (2010) Rice xa13 recessive resistance to bacterial blight is defeated by induction of the disease susceptibility gene Os-11N3. Plant Cell 22:3864-3876

Ao Y, Li Z, Feng D, Xiong F, Liu J, Li JF, Wang M, Wang J, Liu B, Wang HB (2014) OsCERK1 and OsRLCK176 play important roles in peptidoglycan and chitin signaling in rice innate immunity. Plant J 80:1072-1084

Aparna G, Chatterjee A, Sonti RV, Sankaranarayanan R (2009) A cell walldegrading esterase of Xanthomonas oryzae requires a unique substrate recognition module for pathogenesis on rice. Plant Cell 21:1860-1873

Bai J, Choi SH, Ponciano G, Leung H, Leach JE (2000) Xanthomonas oryzae pv. oryzae avirulence genes contribute differently and specifically to pathogen aggressiveness. Mol Plant Microbe Interact 13:1322-1329

Bai P, Park CH, Shirsekar G, Songkumarn P, Bellizzi M, Wang GL (2019) Role of lysine residues of the Magnaporthe oryzae effector AvrPiz-t in effectorand PAMP-triggered immunity. Mol Plant Pathol 20:599-608

Bentur JS, Rawat N, Divya D, Sinha DK, Agarrwal R, Atray I, Nair S (2016) Ricegall midge interactions: battle for survival. J Insect Physiol 84:40-49

Blair MW, Garris AJ, lyer AS, Chapman B, Kresovich S, McCouch SR (2003) High resolution genetic mapping and candidate gene identification at the xa5 locus for bacterial blight resistance in rice (Oryza sativa L.). Theor Appl Genet 107:62-73

Boch J, Bonas U (2010) Xanthomonas AvrBs3 family-type III effectors: discovery and function. Annu Rev Phytopathol 48:419-436

Bogdanove AJ, Koebnik R, Lu H, Furutani A, Angiuoli SV, Patil PB, van Sluys MA, Ryan RP, Meyer DF, Han SW, Aparna G, Rajaram M, Delcher AL, Phillippy AM, Puiu D, Schatz MC, Shumway M, Sommer DD, Trapnell C, Benahmed F, Dimitrov G, Madupu R, Radune D, Sullivan S, Jha G, Ishihara H, Lee SW, Pandey A, Sharma V, Sriariyanun M, Szurek B, Vera-Cruz CM, Dorman KS, Ronald PC, Verdier V, Dow JM, Sonti RV, Tsuge S, Brendel VP, Rabinowicz PD, Leach JE, White FF, Salzberg SL (2011) Two new complete genome sequences offer insight into host and tissue specificity of plant pathogenic Xanthomonas spp. J Bacteriol 193:5450-5464

Bohnert HU, Fudal I, Dioh W, Tharreau D, Notteghem JL, Lebrun MH (2004) A putative polyketide synthase/peptide synthetase from Magnaporthe grisea signals pathogen attack to resistant rice. Plant Cell 16:2499-2513

Bonas U, Stall RE, Staskawicz B (1989) Genetic and structural characterization of the avirulence gene avrBs3 from Xanthomonas campestris pv. vesicatoria. Mol Gen Genet MGG 218:127-136

Burdman S, Shen Y, Lee SW, Xue Q, Ronald P (2004) RaxH/RaxR: a two-component regulatory system in Xanthomonas oryzae pv. oryzae required for AvrXa21 activity. Mol Plant Microbe Interact 17:602-612

Buttner D, Bonas U (2010) Regulation and secretion of Xanthomonas virulence factors. FEMS Microbiol Rev 34:107-133
Carella P, Evangelisti E, Schornack S (2018) Sticking to it: phytopathogen effector molecules may converge on evolutionarily conserved host targets in green plants. Curr Opin Plant Biol 44:175-180

Cesari S, Thilliez G, Ribot C, Chalvon V, Michel C, Jauneau A, Rivas S, Alaux L, Kanzaki H, Okuyama Y, Morel JB, Fournier E, Tharreau D, Terauchi R, Kroj $T$ (2013) The rice resistance protein pair RGA4/RGA5 recognizes the Magnaporthe oryzae effectors AVR-Pia and AVR1-CO39 by direct binding. Plant Cell 25:1463-1481

Chanclud E, Kisiala A, Emery NR, Chalvon V, Ducasse A, Romiti-Michel C, Gravot A, Kroj T, Morel JB (2016) Cytokinin Production by the Rice Blast Fungus Is a Pivotal Requirement for Full Virulence. PLoS Pathog 12:e1005457

Chang JH, Desveaux D, Creason AL (2014) The ABCs and 123s of bacterial secretion systems in plant pathogenesis. Annu Rev Phytopathol 52:317-345

Chen L-Q, Hou B-H, Lalonde S, Takanaga H, Hartung ML, Qu X-Q, Guo W-J, Kim J-G, Underwood W, Chaudhuri B, Chermak D, Antony G, White FF, Somerville SC, Mudgett MB, Frommer WB (2010) Sugar transporters for intercellular exchange and nutrition of pathogens. Nature 468:527-532

Chen X, Liu P, Mei L, He X, Chen L, Liu H, Shen S, Ji Z, Zheng X, Zhang Y, Gao Z, Zeng D, Qian Q, Ma B (2021) Xa7, a new executor R gene that confers durable and broad-spectrum resistance to bacterial blight disease in rice. Plant Commun 2:100143

Cheong H, Kim CY, Jeon JS, Lee BM, Sun Moon J, Hwang I (2013) Xanthomonas oryzae pv. oryzae type III effector XopN targets OsVOZ2 and a putative thiamine synthase as a virulence factor in rice. PLOS ONE 8:e73346

Chinchilla D, Zipfel C, Robatzek S, Kemmerling B, Nurnberger T, Jones JD, Felix G, Boller T (2007) A flagellin-induced complex of the receptor FLS2 and BAK1 initiates plant defence. Nature 448:497-500

Chu Z, Fu B, Yang H, Xu C, Li Z, Sanchez A, Park YJ, Bennetzen JL, Zhang Q, Wang S (2006a) Targeting xa13, a recessive gene for bacterial blight resistance in rice. Theor Appl Genet 112:455-461

Chu Z, Yuan M, Yao J, Ge X, Yuan B, Xu C, Li X, Fu B, Li Z, Bennetzen JL, Zhang Q, Wang S (2006b) Promoter mutations of an essential gene for pollen development result in disease resistance in rice. Genes Dev 20:1250-1255

Collemare J, Pianfetti M, Houlle AE, Morin D, Camborde L, Gagey MJ, Barbisan C, Fudal I, Lebrun MH, Bohnert HU (2008) Magnaporthe grisea avirulence gene ACE1 belongs to an infection-specific gene cluster involved in secondary metabolism. New Phytol 179:196-208

da Silva FG, Shen Y, Dardick C, Burdman S, Yadav RC, de Leon AL, Ronald PC (2004) Bacterial genes involved in type I secretion and sulfation are required to elicit the rice Xa21-mediated innate immune response. Mol Plant Microbe Interact 17:593-601

de Guillen K, Ortiz-Vallejo D, Gracy J, Fournier E, Kroj T, Padilla A (2015) Structure analysis uncovers a highly diverse but structurally conserved effector family in phytopathogenic fungi. PLoS Pathog 11:e1005228

Dean $\mathrm{R}$, van Kan JA, Pretorius ZA, Hammond-Kosack KE, di Pietro A, Spanu PD, Rudd JJ, Dickman M, Kahmann R, Ellis J, Foster GD (2012) The top 10 fungal pathogens in molecular plant pathology. Mol Plant Pathol 13:414-430

Deb S, Gupta MK, Patel HK, Sonti RV (2019) Xanthomonas oryzae pv. oryzae XopQ protein suppresses rice immune responses through interaction with two 14-3-3 proteins but its phospho-null mutant induces rice immune responses and interacts with another 14-3-3 protein. Mol Plant Pathol 20:976-989

Deb S, Ghosh P, Patel HK, Sonti RV (2020) Interaction of the Xanthomonas effectors XopQ and XopX results in induction of rice immune responses. Plant J 104:332-350

Devanna NB, Vijayan J, Sharma TR (2014) The blast resistance gene Pi54of cloned from Oryza officinalis interacts with Avr-Pi54 through its novel non-LRR domains. PLoS ONE 9:e104840

Dong Y, Li Y, Zhao M, Jing M, Liu X, Liu M, Guo X, Zhang X, Chen Y, Liu Y, Liu Y, Ye W, Zhang H, Wang Y, Zheng X, Wang P, Zhang Z (2015) Global genome and transcriptome analyses of Magnaporthe oryzae epidemic isolate 98-06 uncover novel effectors and pathogenicity-related genes, revealing gene gain and lose dynamics in genome evolution. PLoS Pathog 11:e1004801-e1004801

Dou D, Zhou JM (2012) Phytopathogen effectors subverting host immunity: different foes, similar battleground. Cell Host Microbe 12:484-495

Dye DW, Bradbury J, Goto M, Hayward AC, Lelliott RA, Schroth MN (1980) International standards for naming pathovars of phytopathogenic 
bacteria and a list of pathovar names and pathotype strains. Rev Plant Pathol 59(4):153-168

Elazegui F, Islam Z (2003) Diagnosis of common diseases of rice

Elzinga DA, Jander G (2013) The role of protein effectors in plant-aphid interactions. Curr Opin Plant Biol 16:451-456

Eseola AB, Ryder LS, Osés-Ruiz M, Findlay K, Yan X, Cruz-Mireles N, Molinari C, Garduño-Rosales M, Talbot NJ (2021) Investigating the cell and developmental biology of plant infection by the rice blast fungus Magnaporthe oryzae. Fungal Genet Biol 154:103562

Franceschetti M, Maqbool A, Jimenez-Dalmaroni MJ, Pennington HG, Kamoun S, Banfield MJ (2017) Effectors of filamentous plant pathogens: commonalities amid diversity. Microbiol Mol Biol Rev 81:e00066-16

Fujisaki K, Abe Y, Ito A, Saitoh H, Yoshida K, Kanzaki H, Kanzaki E, Utsushi H, Yamashita T, Kamoun S, Terauchi R (2015) Rice Exo70 interacts with a fungal effector, AVR-Pii, and is required for AVR-Pii-triggered immunity. Plant J 83:875-887

Fujita D, Kohli A, Horgan FG (2013) Rice resistance to planthoppers and leafhoppers. Crit Rev Plant Sci 32:162-191

Furutani A, Tsuge S, Ohnishi K, Hikichi Y, Oku T, Tsuno K, Inoue Y, Ochiai H, Kaku H, Kubo Y (2004) Evidence for HrpXo-dependent expression of type II secretory proteins in Xanthomonas oryzae pv. oryzae. J Bacteriol 186:1374-1380

Furutani A, Takaoka M, Sanada H, Noguchi Y, Oku T, Tsuno K, Ochiai H, Tsuge S (2009) Identification of novel type III secretion effectors in Xanthomonas oryzae pv. oryzae. Mol Plant Microbe Interact 22:96-106

Giraldo MC, Dagdas YF, Gupta YK, Mentlak TA, Yi M, Martinez-Rocha AL, Saitoh H, Terauchi R, Talbot NJ, Valent B (2013) Two distinct secretion systems facilitate tissue invasion by the rice blast fungus Magnaporthe oryzae. Nat Commun 4:1996

Gu L, Knipple DC (2013) Recent advances in RNA interference research in insects: implications for future insect pest management strategies. Crop Prot 45:36-40

Gu K, Yang B, Tian D, Wu L, Wang D, Sreekala C, Yang F, Chu Z, Wang GL, White FF, Yin Z (2005) R gene expression induced by a type-III effector triggers disease resistance in rice. Nature 435:1122-1125

Gupta MK, Nathawat R, Sinha D, Haque AS, Sankaranarayanan R, Sonti RV (2015) Mutations in the predicted active site of Xanthomonas oryzae pv. oryzae XopQ differentially affect virulence, suppression of host innate immunity, and induction of the HR in a nonhost plant. Mol Plant Microbe Interact 28:195-206

Gurlebeck D, Thieme F, Bonas U (2006) Type III effector proteins from the plant pathogen Xanthomonas and their role in the interaction with the host plant. J Plant Physiol 163:233-255

Hattori M, Tsuchihara K, Noda H, Konishi H, Tamura Y, Shinoda T, Nakamura M, Hasegawa T (2010) Molecular characterization and expression of laccase genes in the salivary glands of the green rice leafhopper, Nephotettix cincticeps (Hemiptera: Cicadellidae). Insect Biochem Mol Biol 40:331-338

Hattori M, Nakamura M, Komatsu S, Tsuchihara K, Tamura Y, Hasegawa T (2012) Molecular cloning of a novel calcium-binding protein in the secreted saliva of the green rice leafhopper Nephotettix cincticeps. Insect Biochem Mol Biol 42:1-9

Hattori M, Komatsu S, Noda H, Matsumoto Y (2015) Proteome analysis of watery saliva secreted by green rice leafhopper, Nephotettix cincticeps. PLOS ONE 10:e0123671

Hopkins CM, White F, Choi S, Guo A, Leach J (1992) Identification of a family of avirulence genes from Xanthomonas oryzae pv. oryzae. Mol PlantMicrobe Interact 5:451-459

Hu J, Qian W, He C (2007) The Xanthomonas oryzae pv. oryzae egIXoB endoglucanase gene is required for virulence to rice. FEMS Microbiol Lett 269:273-279

Huang HJ, Liu CW, Cai YF, Zhang MZ, Bao YY, Zhang CX (2015) A salivary sheath protein essential for the interaction of the brown planthopper with rice plants. Insect Biochem Mol Biol 66:77-87

Huang HJ, Liu CW, Huang XH, Zhou X, Zhuo JC, Zhang CX, Bao YY (2016) Screening and functional analyses of Nilaparvata lugens salivary proteome. J Proteome Res 15:1883-1896

Huang HJ, Liu CW, Xu HJ, Bao YY, Zhang CX (2017) Mucin-like protein, a saliva component involved in brown planthopper virulence and host adaptation. J Insect Physiol 98:223-230
Huang H-J, Cui J-R, Xia X, Chen J, Ye Y-X, Zhang C-X, Hong X-Y (2019a) Salivary DNase II from Laodelphax striatellus acts as an effector that suppresses plant defence. New Phytol 224:860-874

Huang HJ, Zhang CX, Hong XY (2019b) How does saliva function in planthopper-host interactions? Arch Insect Biochem Physiol 100:e21537

Irieda H, Inoue Y, Mori M, Yamada K, Oshikawa Y, Saitoh H, Uemura A, Terauchi R, Kitakura S, Kosaka A, Singkaravanit-Ogawa S, Takano Y (2019) Conserved fungal effector suppresses PAMP-triggered immunity by targeting plant immune kinases. Proc Natl Acad Sci USA 116:496-505

Ishikawa K, Yamaguchi K, Sakamoto K, Yoshimura S, Inoue K, Tsuge S, Kojima C, Kawasaki T (2014) Bacterial effector modulation of host E3 ligase activity suppresses PAMP-triggered immunity in rice. Nat Commun 5:5430

Iyer AS, McCouch SR (2004) The rice bacterial blight resistance gene xa5 encodes a novel form of disease resistance. Mol Plant Microbe Interact 17:1348-1354

Jha G, Rajeshwari R, Sonti RV (2005) Bacterial type two secretion system secreted proteins: double-edged swords for plant pathogens. Mol Plant Microbe Interact 18:891-898

Jha G, Rajeshwari R, Sonti RV (2007) Functional interplay between two Xanthomonas oryzae pv, oryzae secretion systems in modulating virulence on rice. Mol Plant Microbe Interact 20:31-40

Ji R, Yu H, Fu Q, Chen H, Ye W, Li S, Lou Y (2013) Comparative transcriptome analysis of salivary glands of two populations of rice brown planthopper, Nilaparvata lugens, that differ in virulence. PLOS ONE, 8, e79612

Ji Z, Ji C, Liu B, Zou L, Chen G, Yang B (2016) Interfering TAL effectors of Xanthomonas oryzae neutralize R-gene-mediated plant disease resistance. Nat Commun 7:13435

Ji R, Ye W, Chen H, Zeng J, Li H, Yu H, Li J, Lou Y (2017) A salivary endo-beta-1,4glucanase acts as an effector that enables the brown planthopper to feed on rice. Plant Physiol 173:1920-1932

Ji C, Ji Z, Liu B, Cheng H, Liu H, Liu S, Yang B, Chen G (2020a) Xa1 allelic R genes activate rice blight resistance suppressed by interfering TAL effectors. Plant Commun 1:100087

Ji H, Liu D, Zhang Z, Sun J, Han B, Li Z (2020b) A bacterial F-box effector suppresses SAR immunity through mediating the proteasomal degradation of OsTrxh2 in rice. Plant J 104:1054-1072

Jia Y, McAdams SA, Bryan GT, Hershey HP, Valent B (2000) Direct interaction of resistance gene and avirulence gene products confers rice blast resistance. Embo J 19:4004-4014

Jones K, Kim DW, Park JS, Khang CH (2016) Live-cell fluorescence imaging to investigate the dynamics of plant cell death during infection by the rice blast fungus Magnaporthe oryzae. BMC Plant Biol 16:69

Kang S, Sweigard JA, Valent B (1995) The PWL host specificity gene family in the blast fungus Magnaporthe grisea. Mol Plant Microbe Interact 8:939-948

Kanzaki H, Yoshida K, Saitoh H, Fujisaki K, Hirabuchi A, Alaux L, Fournier E, Tharreau D, Terauchi R (2012) Arms race co-evolution of Magnaporthe oryzae AVR-Pik and rice Pik genes driven by their physical interactions. Plant J 72:894-907

Khan M, Seto D, Subramaniam R, Desveaux D (2018) Oh, the places they'll go! A survey of phytopathogen effectors and their host targets. Plant J 93:651-663

Khang CH, Berruyer R, Giraldo MC, Kankanala P, Park SY, Czymmek K, Kang S, Valent B (2010) Translocation of Magnaporthe oryzae effectors into rice cells and their subsequent cell-to-cell movement. Plant Cell 22:1388-1403

KHUSH, G. S. (2005) What it will take to feed 5.0 billion rice consumers in 2030. Plant Mol Biol 59:1-6

Konishi H, Noda H, Tamura Y, Hattori M (2009) Proteomic analysis of the salivary glands of the rice brown planthopper, Nilaparvata lugens (Stål) (Homoptera: Delphacidae). Appl Entomol Zool 44:525-534

Lee BM, Park YJ, Park DS, Kang HW, Kim JG, Song ES, Park IC, Yoon UH, Hahn JH, Koo BS, Lee GB, Kim H, Park HS, Yoon KO, Kim JH, Jung CH, Koh NH, Seo JS, Go SJ (2005) The genome sequence of Xanthomonas oryzae pathovar oryzae KACC10331, the bacterial blight pathogen of rice. Nucleic Acids Res 33:577-586

Li W, Wang B, Wu J, Lu G, Hu Y, Zhang X, Zhang Z, Zhao Q, Feng Q, Zhang H, Wang Z, Wang G, Han B, Wang Z, Zhou B (2009) The Magnaporthe oryzae avirulence gene AvrPiz-t encodes a predicted secreted protein that triggers the immunity in rice mediated by the blast resistance gene Piz-t. Mol Plant Microbe Interact 22:41 1-420 
Li R, Wang S, Sun R, He X, Liu Y, Song C (2018a) Xanthomonas oryzae pv. oryzae type III effector PthXo3JXOV suppresses innate immunity, induces susceptibility and binds to multiple targets in rice. FEMS Microbiol Lett. https://doi.org/10.1093/femsle/fny037

Li T, Wen J, Zhang Y, Correll J, Wang L, Pan Q (2018b) Reconstruction of an SSR-based Magnaporthe oryzae physical map to locate avirulence gene AvrPi12. BMC Microbiol 18:47

Li Y, Liu X, Liu M, Wang Y, Zou Y, You Y, Yang L, Hu J, Zhang H, Zheng X, Wang P, Zhang Z (2020) Magnaporthe oryzae auxiliary activity protein MoAa91 Functions as chitin-binding protein to induce Appressorium Formation on artificial inductive surfaces and suppress plant immunity. Mbio 11:e03304-19

Liu X, Zhou H, Zhao J, Hua H, He Y (2016) Identification of the secreted watery saliva proteins of the rice brown planthopper, Nilaparvata lugens (Stal) by transcriptome and Shotgun LC-MS/MS approach. J Insect Physiol 89:60-69

Long J, Song C, Yan F, Zhou J, Zhou H, Yang B (2018) Non-TAL effectors from Xanthomonas oryzae pv. oryzae suppress peptidoglycan-triggered MAPK activation in rice. Front Plant Sci 9:1857

Ma W, Zou L, Zhiyuan JI, Xiameng XU, Zhengyin XU, Yang Y, Alfano JR, Chen G (2018) Xanthomonas oryzae pv. oryzae TALE proteins recruit OsTFIIAgamma1 to compensate for the absence of OsTFIIAgamma5 in bacterial blight in rice. Mol Plant Pathol 19:2248-2262

Ma W, Xu X, Cai L, Cao Y, Haq F, Alfano JR, Zhu B, Zou L, Chen G (2020) A Xanthomonas oryzae type III effector XopL causes cell death through mediating ferredoxin degradation in Nicotiana benthamiana. Phytopathol Res 2:16

Matsumoto Y, Hattori M (2018) The green rice leafhopper, Nephotettix cincticeps (Hemiptera: Cicadellidae), salivary protein NcSP75 is a key effector for successful phloem ingestion. PLOS ONE 13:e0202492

Matsumoto Y, Suetsugu Y, Nakamura M, Hattori M (2014) Transcriptome analysis of the salivary glands of Nephotettix cincticeps (Uhler). J Insect Physiol 71:170-176

Mentlak TA, Kombrink A, Shinya T, Ryder LS, Otomo I, Saitoh H, Terauchi R, Nishizawa Y, Shibuya N, Thomma BP, Talbot NJ (2012) Effector-mediated suppression of chitin-triggered immunity by Magnaporthe oryzae is necessary for rice blast disease. Plant Cell 24:322-335

Miao Y, Jia H, Li Z, Liu Y, Hou M (2018a) Transcriptomic and expression analysis of the salivary glands in Brown Planthoppers, Nilaparvata lugens (Hemiptera: Delphacidae). J Econ Entomol 111:2884-2893

Miao YT, Deng Y, Jia HK, Liu YD, Hou ML (2018b) Proteomic analysis of watery saliva secreted by white-backed planthopper, Sogatella furcifera. PLoS ONE 13:e0193831

Mogga V, Delventhal R, Weidenbach D, Langer S, Bertram PM, Andresen K, Thines E, Kroj T, Schaffrath U (2016) Magnaporthe oryzae effectors MoHEG13 and MoHEG16 interfere with host infection and MoHEG13 counteracts cell death caused by Magnaporthe-NLPs in tobacco. Plant Cell Rep 35:1169-1185

Mondal KK, Verma G, Junaid MA, Mani C (2016) Rice pathogen Xanthomonas oryzae pv oryzae employs inducible hrp-dependent XopF type III effector protein for its growth, pathogenicity and for suppression of PTI response to induce blight disease. Eur J Plant Pathol 144:311-323

Mosquera G, Giraldo MC, Khang CH, Coughlan S, Valent B (2009) Interaction transcriptome analysis identifies Magnaporthe oryzae BAS1-4 as Biotrophy-associated secreted proteins in rice blast disease. Plant Cell 21:1273-1290

Mücke S, Reschke M, Erkes A, Schwietzer CA, Becker S, Streubel J, Morgan RD, Wilson GG, Grau J, Boch J (2019) Transcriptional reprogramming of rice cells by Xanthomonas oryzae TALEs. Front Plant Sci 10:162

Mudgertt MB (2005) New insights to the function of phytopathogenic bacterial type III effectors in plants. Annu Rev Plant Biol 56:509-531

Nakamura M, Hattori M (2013) Purification of $\beta$-glucosidase from the salivary glands of the green rice leafhopper, Nephotettix cincticeps (Uhler) (Hemiptera: Cicadellidae), and its detection in the salivary sheath. Appl Entomol Zool 48:489-497

Park CH, Chen S, Shirsekar G, Zhou B, Khang CH, Songkumarn P, Afzal AJ, Ning Y, Wang R, Bellizzi M, Valent B, Wang GL (2012) The Magnaporthe oryzae effector AvrPiz-t targets the RING E3 ubiquitin ligase APIP6 to suppress pathogen-associated molecular pattern-triggered immunity in rice. Plant Cell 24:4748-4762
Park CH, Shirsekar G, Bellizzi M, Chen S, Songkumarn P, Xie X, Shi X, Ning Y, Zhou B, Suttiviriya P, Wang M, Umemura K, Wang GL (2016) The E3 ligase APIP10 connects the effector AvrPiz-t to the NLR receptor Piz-t in rice. PLoS Pathog 12:e1005529

Patkar RN, Benke PI, Qu Z, Chen YY, Yang F, Swarup S, Naqvi NI (2015) A fungal monooxygenase-derived jasmonate attenuates host innate immunity. Nat Chem Biol 11:733-740

Pennisi A (2010) Armed and dangerous. Science 327:804-805

Petrova A, Smith CM (2014) Immunodetection of a brown planthopper (Nilaparvata lugens Stal) salivary catalase-like protein into tissues of rice, Oryza sativa. Insect Mol Biol 23:13-25

Petrova A, Smith CM (2015) Application of Brown Planthopper salivary gland extract to rice plants induces systemic host mRNA patterns associated with nutrient remobilization. PLoS ONE 10:e0141769

Pruitt RN, Schwessinger B, Joe A, Thomas N, Liu F, Albert M, Robinson MR, Chan LJG, Luu DD, Chen H, Bahar O, Daudi A, de Vleesschauwer D, Caddell D, Zhang W, Zhao X, Li X, Heazlewood JL, Ruan D, Majumder D, Chern M, Kalbacher H, Midha S, Patil PB, Sonti RV, Petzold CJ, Liu CC, Brodbelt JS, Felix G, Ronald PC (2015) The rice immune receptor XA21 recognizes a tyrosine-sulfated protein from a Gram-negative bacterium. Sci Adv 1:e1500245

Qian G, Zhou Y, Zhao Y, Song Z, Wang S, Fan J, Hu B, Venturi V, Liu F (2013) Proteomic analysis reveals novel extracellular virulence-associated proteins and functions regulated by the diffusible signal factor (DSF) in Xanthomonas oryzae pv. oryzicola. J Proteome Res 12:3327-3341

Quintana-Rodriguez E, Duran-Flores D, Heil M, Camacho-Coronel X (2018) Damage-associated molecular patterns (DAMPs) as future plant vaccines that protect crops from pests. Sci Hortic 237:207-220

Rajeshwari R, Jha G, Sonti RV (2005) Role of an in planta-expressed xylanase of Xanthomonas oryzae pv. oryzae in promoting virulence on rice. Mol Plant Microbe Interact 18:830-837

Rao W, Zheng X, Liu B, Guo Q, Guo J, Wu Y, Shangguan X, Wang H, Wu D, Wang Z, Hu L, Xu C, Jiang W, Huang J, Shi S, He G (2019) Secretome analysis and in planta expression of salivary proteins identify candidate effectors from the Brown Planthopper Nilaparvata lugens. Mol Plant Microbe Interact 32:227-239

Ray SK, Rajeshwari R, Sonti RV (2000) Mutants of Xanthomonas oryzae pv. oryzae deficient in general secretory pathway are virulence deficient and unable to secrete xylanase. Mol Plant Microbe Interact 13:394-401

Read AC, Rinaldi FC, Hutin M, He YQ, Triplett LR, Bogdanove AJ (2016) Suppression of $\mathrm{X}_{0} 1$-mediated disease resistance in rice by a truncated, non-DNA-binding TAL effector of Xanthomonas oryzae. Front Plant Sci 7:1516

Ribot C, Cesari S, Abidi I, Chalvon V, Bournaud C, Vallet J, Lebrun MH, Morel JB, Kroj T (2013) The Magnaporthe oryzae effector AVR1-CO39 is translocated into rice cells independently of a fungal-derived machinery. Plant J 74:1-12

Rodriguez PA, Bos II (2013) Toward understanding the role of aphid effectors in plant infestation. Mol Plant Microbe Interact 26:25-30

Saitoh H, Fujisawa S, Mitsuoka C, Ito A, Hirabuchi A, Ikeda K, Irieda H, Yoshino K, Yoshida K, Matsumura H, Tosa Y, Win J, Kamoun S, Takano Y, Terauchi $R$ (2012) Large-scale gene disruption in Magnaporthe oryzae identifies MC69, a secreted protein required for infection by monocot and dicot fungal pathogens. PLoS Pathog 8:e002711

Sakulkoo W, Oses-Ruiz M, Oliveira Garcia E, Soanes DM, Littlejohn GR, Hacker C, Correia A, Valent B, Talbot NJ (2018) A single fungal MAP kinase controls plant cell-to-cell invasion by the rice blast fungus. Science 359:1399-1403

Salzberg SL, Sommer DD, Schatz MC, Phillippy AM, Rabinowicz PD, Tsuge S, Furutani A, Ochiai H, Delcher AL, Kelley D, Madupu R, Puiu D, Radune D, Shumway M, Trapnell C, Aparna G, Jha G, Pandey A, Patil PB, Ishihara H, Meyer DF, Szurek B, Verdier V, Koebnik R, Dow JM, Ryan RP, Hirata H, Tsuyumu S, Won Lee S, Ronald PC, Sonti RV, Van Sluys M-A, Leach JE, White FF, Bogdanove AJ (2008) Genome sequence and rapid evolution of the rice pathogen Xanthomonas oryzae pv. oryzae PXO99A. BMC Genomics 9:204

Shangguan X, Zhang J, Liu B, Zhao Y, Wang H, Wang Z, Guo J, Rao W, Jing S, Guan W, Ma Y, Wu Y, Hu L, Chen R, Du B, Zhu L, Yu D, He G (2018) A Mucin-like protein of planthopper is required for feeding and induces immunity response in plants. Plant Physiol 176:552-565 
Shen Y, Ronald P (2002) Molecular determinants of disease and resistance in interactions of Xanthomonas oryzae pv. oryzae and rice. Microbes Infect 4:1361-1367

Shi X, Long Y, He F, Zhang C, Wang R, Zhang T, Wu W, Hao Z, Wang Y, Wang GL, Ning $Y$ (2018) The fungal pathogen Magnaporthe oryzae suppresses innate immunity by modulating a host potassium channel. PLOS Pathog 14:e1006878

Shinya T, Hojo Y, Desaki Y, Christeller JT, Okada K, Shibuya N, Galis I (2016) Modulation of plant defense responses to herbivores by simultaneous recognition of different herbivore-associated elicitors in rice. Sci Rep 6:32537

Shipman EN, Jones K, Jenkinson CB, Kim DW, Zhu J, Khang CH (2017) Nuclear and structural dynamics during the establishment of a specialized effector-secreting cell by Magnaporthe oryzae in living rice cells. BMC Cell Biol 18:11

Singh R, Dangol S, Chen Y, Choi J, Cho YS, Lee JE, Choi MO, Jwa NS (2016) Magnaporthe oryzae effector AVR-Pii helps to establish compatibility by inhibition of the rice NADP-Malic enzyme resulting in disruption of oxidative burst and host innate immunity. Mol Cells 39:426-438

Sinha DK, Bentur JS, Nair S (2011) Compatible interaction with its rice host leads to enhanced expression of the gamma subunit of oligosaccharyl transferase in the Asian rice gall midge, Orseolia oryzae. Insect Mol Biol 20:567-575

Sinha DK, Atray I, Bentur JS, Nair S (2012) Expression of Orseolia oryzae nucleoside diphosphate kinase (OoNDPK) is enhanced in rice gall midge feeding on susceptible rice hosts and its over-expression leads to salt tolerance in Escherichia coli. Insect Mol Biol 21:593-603

Sogawa C (1967) Chemical Nature of the Sheath Materials Secreted by Leafhoppers (Homoptera). Appl Entomol Zool 2:13-21

Sōgawa C (1982) THE RICE BROWN PLANTHOPPER: feeding physiology and host plant interactions. Annu Rev Entomol 27:49-73

Song C, Yang B (2010) Mutagenesis of 18 type III effectors reveals virulence function of XopZ(PXO99) in Xanthomonas oryzae pv. oryzae. Mol Plant Microbe Interact 23:893-902

Song WY, Wang GL, Chen LL, Kim HS, Pi LY, Holsten T, Gardner J, Wang B, Zhai WX, Zhu LH, Fauquet C, Ronald P (1995) A receptor kinase-like protein encoded by the rice disease resistance gene, Xa21. Science 270:1804-1806

Streubel J, Pesce C, Hutin M, Koebnik R, Boch J, Szurek B (2013) Five phylogenetically close rice SWEET genes confer TAL effector-mediated susceptibility to Xanthomonas oryzae pv. oryzae. New Phytol 200:808-819

Sugio A, Yang B, Zhu T, White FF (2007) Two type III effector genes of Xanthomonas oryzae pv. oryzae control the induction of the host genes OsTFIIAgamma1 and OsTFX1 during bacterial blight of rice. Proc Natl Acad Sci USA 104:10720-10725

Sun X, Cao Y, Yang Z, Xu C, Li X, Wang S, Zhang Q (2004) Xa26, a gene conferring resistance to Xanthomonas oryzae pv. oryzae in rice, encodes an LRR receptor kinase-like protein. Plant J 37:517-527

Sun QH, Hu J, Huang GX, Ge C, Fang RX, He CZ (2005) Type-II secretion pathway structural gene xpsE, xylanase- and cellulase secretion and virulence in Xanthomonas oryzae pv. oryzae. Plant Pathol 54:15-21

Sweigard JA, Carroll AM, Kang S, Farrall L, Chumley FG, Valent B (1995) Identification, cloning, and characterization of PWL2, a gene for host species specificity in the rice blast fungus. Plant Cell 7:1221-1233

Tang M, Ning Y, Shu X, Dong B, Zhang H, Wu D, Wang H, Wang GL, Zhou B (2017) The Nup98 homolog APIP12 targeted by the effector AvrPiz-t is involved in rice basal resistance against Magnaporthe oryzae. Rice (n Y) 10:5

Tayi L, Maku R, Patel HK, Sonti RV (2016a) Action of multiple cell wall-degrading enzymes is required for elicitation of innate immune responses during Xanthomonas oryzae pv. oryzae infection in rice. Mol Plant Microbe Interact 29:599-608

Tayi L, Maku RV, Patel HK, Sonti RV (2016b) Identification of pectin degrading enzymes secreted by Xanthomonas oryzae pv. oryzae and determination of their role in virulence on rice. PLOS ONE 11:66396

Tayi L, Kumar S, Nathawat R, Haque AS, Maku RV, Patel HK, Sankaranarayanan R, Sonti RV (2018) A mutation in an exoglucanase of Xanthomonas oryzae pv. oryzae, which confers an endo mode of activity, affects bacterial virulence, but not the induction of immune responses, in rice. Mol Plant Pathol 19:1364-1376
Tian D, Wang J, Zeng X, Gu K, Qiu C, Yang X, Zhou Z, Goh M, Luo Y, Murata-Hori $M$, White FF, Yin $Z$ (2014) The rice TAL effector-dependent resistance protein XA10 triggers cell death and calcium depletion in the endoplasmic reticulum. Plant Cell 26:497-515

Toruno TY, Stergiopoulos I, Coaker G (2016) Plant-pathogen effectors: cellular probes interfering with plant defenses in spatial and temporal manners. Annu Rev Phytopathol 54:419-441

Tran TT, Perez-Quintero AL, Wonni I, Carpenter SCD, Yu Y, Wang L, Leach JE, Verdier V, Cunnac S, Bogdanove AJ, Koebnik R, Hutin M, Szurek B (2018) Functional analysis of African Xanthomonas oryzae pv. oryzae TALomes reveals a new susceptibility gene in bacterial leaf blight of rice. PLoS Pathog 14:e1007092

Triplett LR, Cohen SP, Heffelfinger C, Schmidt CL, Huerta Al, Tekete C, Verdier V, Bogdanove AJ, Leach JE (2016) A resistance locus in the American heirloom rice variety Carolina Gold Select is triggered by TAL effectors with diverse predicted targets and is effective against African strains of Xanthomonas oryzae pv. oryzicola. Plant J 87:472-483

van Buyten E, Hofte M (2013) Pythium species from rice roots differ in virulence, host colonization and nutritional profile. BMC Plant Biol 13:203

Varden FA, de la Concepcion JC, Maidment JH, Banfield MJ (2017) Taking the stage: effectors in the spotlight. Curr Opin Plant Biol 38:25-33

Wang Y, Wang Y (2018) Trick or treat: microbial pathogens evolved apoplastic effectors modulating plant susceptibility to infection. Mol Plant Microbe Interact 31:6-12

Wang YS, Pi LY, Chen X, Chakrabarty PK, Jiang J, de Leon AL, Liu GZ, Li L, Benny U, Oard J, Ronald PC, Song WY (2006) Rice XA21 binding protein 3 is a ubiquitin ligase required for full Xa21-mediated disease resistance. Plant Cell 18:3635-3646

Wang X, Kota U, He K, Blackburn K, Li J, Goshe MB, Huber SC, Clouse SD (2008) Sequential transphosphorylation of the BRI1/BAK1 receptor kinase complex impacts early events in brassinosteroid signaling. Dev Cell 15:220-235

Wang CL, Qin TF, Yu HM, Zhang XP, Che JY, Gao Y, Zheng CK, Yang B, Zhao KJ (2014) The broad bacterial blight resistance of rice line CBB23 is triggered by a novel transcription activator-like (TAL) effector of Xanthomonas oryzae pv. oryzae. Mol Plant Pathol 15:333-341

Wang C, Zhang X, Fan Y, Gao Y, Zhu Q, Zheng C, Qin T, Li Y, Che J, Zhang M, Yang B, Liu Y, Zhao K (2015) XA23 is an executor R protein and confers broad-spectrum disease resistance in rice. Mol Plant 8:290-302

Wang R, Ning Y, Shi X, He F, Zhang C, Fan J, Jiang N, Zhang Y, Zhang T, Hu Y, Bellizzi M, Wang GL (2016a) Immunity to rice blast disease by suppression of effector-triggered necrosis. Curr Biol 26:2399-2411

Wang S, Sun J, Fan F, Tan Z, Zou Y, Lu D (2016b) A Xanthomonas oryzae pv. oryzae effector, XopR, associates with receptor-like cytoplasmic kinases and suppresses PAMP-triggered stomatal closure. Sci China Life Sci 59:897-905

Wang Y, Wu J, Kim SG, Tsuda K, Gupta R, Park SY, Kim ST, Kang KY (2016c) Magnaporthe oryzae-secreted protein MSP1 induces cell death and elicits defense responses in rice. Mol Plant Microbe Interact 29:299-312

Wang C, Wang G, Zhang C, Zhu P, Dai H, Yu N, He Z, Xu L, Wang E (2017) OsCERK1-mediated chitin perception and immune signaling requires receptor-like cytoplasmic kinase 185 to activate an MAPK cascade in rice. Mol Plant 10:619-633

Weber E, Ojanen-Reuhs T, Huguet E, Hause G, Romantschuk M, Korhonen TK, Bonas U, Koebnik R (2005) The type III-dependent Hrp pilus is required for productive interaction of Xanthomonas campestris pv. vesicatoria with pepper host plants. J Bacteriol 187:2458-2468

White FF, Yang B (2009) Host and pathogen factors controlling the rice-Xanthomonas oryzae interaction. Plant Physiol 150:1677-1686

Wilkins KE, Booher NJ, Wang L, Bogdanove AJ (2015) TAL effectors and activation of predicted host targets distinguish Asian from African strains of the rice pathogen Xanthomonas oryzae pv. oryzicola while strict conservation suggests universal importance of five TAL effectors. Front Plant Sci 6:536

Wu J, Kou Y, Bao J, Li Y, Tang M, Zhu X, Ponaya A, Xiao G, Li J, Li C, Song MY, Cumagun CJ, Deng Q, Lu G, Jeon JS, Naqvi NI, Zhou B (2015) Comparative genomics identifies the Magnaporthe oryzae avirulence effector AvrPi9 that triggers Pi9-mediated blast resistance in rice. New Phytol 206:1463-1475 
Xiang Y, Cao Y, Xu C, Li X, Wang S (2006) Xa3, conferring resistance for rice bacterial blight and encoding a receptor kinase-like protein, is the same as Xa26. Theor Appl Genet 113:1347-1355

Yamaguchi K, Nakamura Y, Ishikawa K, Yoshimura Y, Tsuge S, Kawasaki T (2013a) Suppression of rice immunity by Xanthomonas oryzae type III effector Xoo2875. Biosci Biotechnol Biochem 77:796-801

Yamaguchi K, Yamada K, Ishikawa K, Yoshimura S, Hayashi N, Uchihashi K, Ishihama N, Kishi-Kaboshi M, Takahashi A, Tsuge S, Ochiai H, Tada Y, Shimamoto K, Yoshioka H, Kawasaki T (2013b) A receptor-like cytoplasmic kinase targeted by a plant pathogen effector is directly phosphorylated by the chitin receptor and mediates rice immunity. Cell Host Microbe 13:347-357

Yan X, Talbot NJ (2016) Investigating the cell biology of plant infection by the rice blast fungus Magnaporthe oryzae. Curr Opin Microbiol 34:147-153

Yang B, White FF (2004) Diverse members of the AvrBs3/PthA family of type III effectors are major virulence determinants in bacterial blight disease of rice. Mol Plant Microbe Interact 17:1192-1200

Yang B, Sugio A, White FF (2006) Os8N3 is a host disease-susceptibility gene for bacterial blight of rice. Proc Natl Acad Sci USA 103:10503-10508

Ye W, Yu H, Jian Y, Zeng J, Ji R, Chen H, Lou Y (2017) A salivary EF-hand calciumbinding protein of the brown planthopper Nilaparvata lugens functions as an effector for defense responses in rice. Sci Rep 7:40498

Yoshida K, Saitoh H, Fujisawa S, Kanzaki H, Matsumura H, Yoshida K, Tosa Y, Chuma I, Takano Y, Win J, Kamoun S, Terauchi R (2009) Association genetics reveals three novel avirulence genes from the rice blast fungal pathogen Magnaporthe oryzae. Plant Cell 21:1573-1591

Yoshimura S, Yamanouchi U, Katayose Y, Toki S, Wang ZX, Kono I, Kurata N, Yano M, Iwata N, Sasaki T (1998) Expression of Xa1, a bacterial blight-resistance gene in rice, is induced by bacterial inoculation. Proc Natl Acad Sci USA 95:1663-1668

Yuan M, Wang S (2013) Rice MtN3/saliva/SWEET family genes and their homologs in cellular organisms. Mol Plant 6:665-674
Yuan M, Chu Z, Li X, Xu C, Wang S (2009) Pathogen-induced expressional loss of function is the key factor in race-specific bacterial resistance conferred by a recessive R gene xa13 in rice. Plant Cell Physiol 50:947-955

Yun CS, Motoyama T, Osada H (2015) Biosynthesis of the mycotoxin tenuazonic acid by a fungal NRPS-PKS hybrid enzyme. Nat Commun 6:8758

Zhang S, Wang L, Wu W, He L, Yang X, Pan Q (2015) Function and evolution of Magnaporthe oryzae avirulence gene AvrPib responding to the rice blast resistance gene Pib. Sci Rep 5:11642

Zhang C, Fang H, Shi X, He F, Wang R, Fan J, Bai P, Wang J, Park CH, Bellizzi M, Zhou X, Wang GL, Ning Y (2020) A fungal effector and a rice NLR protein have antagonistic effects on a Bowman-Birk trypsin inhibitor. Plant Biotechnol J 18:2354-2363

Zhao S, Mo WL, Wu F, Tang W, Tang JL, Szurek B, Verdier V, Koebnik R, Feng JX (2013) Identification of non-TAL effectors in Xanthomonas oryzae pv. oryzae Chinese strain 13751 and analysis of their role in the bacterial virulence. World J Microbiol Biotechnol 29:733-744

Zhou J, Peng Z, Long J, Sosso D, Liu B, Eom JS, Huang S, Liu S, Vera Cruz C, Frommer WB, White FF, Yang B (2015) Gene targeting by the TAL effector $\mathrm{Pth} \mathrm{X}_{\mathrm{O} 2}$ reveals cryptic resistance gene for bacterial blight of rice. Plant J 82:632-643

Zou HS, Song X, Zou LF, Yuan L, Li YR, Guo W, Che YZ, Zhao WX, Duan YP, Chen GY (2012) EcpA, an extracellular protease, is a specific virulence factor required by Xanthomonas oryzae $\mathrm{pv}$. oryzicola but not by $X$. oryzae $\mathrm{pv}$. oryzae in rice. Microbiology 158:2372-2383

\section{Publisher's Note}

Springer Nature remains neutral with regard to jurisdictional claims in published maps and institutional affiliations.

\section{Submit your manuscript to a SpringerOpen ${ }^{\circ}$ journal and benefit from:}

- Convenient online submission

- Rigorous peer review

- Open access: articles freely available online

- High visibility within the field

- Retaining the copyright to your article

Submit your next manuscript at $\boldsymbol{\nabla}$ springeropen.com 